OPEN ACCESS

Edited by: Sohom Mandal,

Canadian National Railway, Canada

Reviewed by:

Jorge Eduardo Teixeira Leandro, University of Siegen, Germany

Tracy Lynn Kijewski-Correa,

University of Notre Dame,

United States

*Correspondence:

Dan Sandink

dsandink@iclr.org

Specialty section This article was submitted to Water and Built Environment, a section of the journal

Frontiers in Water

Received: 31 March 2021

Accepted: 06 July 2021

Published: 23 August 2021

Citation:

Sandink D and Binns AD (2021) Reducing Urban Flood Risk Through

Building- and Lot-Scale Flood Mitigation Approaches: Challenges and Opportunities.

Front. Water 3:689202.

doi: 10.3389/frwa.2021.689202

\section{Reducing Urban Flood Risk Through Building- and Lot-Scale Flood Mitigation Approaches: Challenges and Opportunities}

\author{
Dan Sandink ${ }^{1 *}$ and Andrew D. Binns ${ }^{2}$ \\ ${ }^{1}$ Institute for Catastrophic Loss Reduction, Toronto, ON, Canada, ${ }^{2}$ School of Engineering, University of Guelph, Guelph, ON, \\ Canada
}

Urban flooding events are a significant driver of disaster loss, resulting in insured and uninsured losses, property damage, and negative impacts on residents and communities in Canada and internationally. The risk of flooding in urban environments is affected by watershed characteristics, environmental conditions, and the presence and condition of flood management and mitigation technologies. Several building- and lot-scale (or private-side) flood mitigation options are available to better protect properties from the risk of flooding, including backwater valves and foundation drainage systems to reduce the risks of sewer surcharge and infiltration flooding into basements, respectively. The overall success of private-side approaches to reduce the risk of flooding into buildings is reliant upon consistent installation procedures, building code interpretation and enforcement, public engagement, and maintenance. Current research into private-side approaches is presenting many opportunities and solutions for improved flood protection against water-related disasters at home. A greater understanding of the performance of private-side technologies under complex site-specific conditions can help to appoint flood prevention strategies better suited to individual home characteristics. This review paper explores the inter-related factors that affect the risk of basement flooding and explores the challenges and opportunities associated with the adoption and success of private-side flood mitigation approaches. Developing a greater understanding of basement flood vulnerability at the lot-scale will assist in identifying and prioritizing private-side strategies for homeowners to adopt and reduce the risk of flooding based on site-specific conditions affecting flood vulnerability. Continued efforts to evaluate and identify flood risk factors and the performance of private-side strategies are needed to better manage urban flooding events.

Keywords: urban flooding, basement flooding, flood mitigation, private-side approaches, wastewater, stormwater, Canada, flood risk 


\section{INTRODUCTION}

Urban flooding results from large and often rapid (or flashy) precipitation (or pluvial) events that overwhelm drainage infrastructure, resulting in flooded streets and basements. Issues concerning urban flooding have been identified in regions across the globe (Zhu and Chen, 2017; Mobini et al., 2020; Pagliacci et al., 2020). In Canada, urban and basement flooding is one of the most significant drivers of disaster loss. The July 8, 2013 short duration, high intensity (SDHI) flood event in the Greater Toronto Area of Ontario highlights the potential for significant damage from urban and basement flooding. Totaling \$1.024 B (2019 CAD), this event currently ranks as the fourth most expensive insurance catastrophe event in the past 20 years in Canada, behind only the Horse River Wildland Urban Interface fire event, the 2013 floods in S. Alberta, and the 2020 hail, flood and wind event in S. Alberta (Insurance Bureau of Canada, 2020).

Table 1 provides an indication of insured loss from urban and basement flood events. A significant portion of loss is uninsured, including losses attributed to uninsured flood types, such as infiltration and potentially overland flood in many instances.

Urban and basement flooding resulting from pluvial events have many non-monetary and indirect impacts. Vulnerable residents, including those occupying basement apartments, are particularly affected by urban flood events. The issue of vulnerable basement apartment residents will be exacerbated as planning policy in highly urbanized regions increasingly emphasizes basement apartments as affordable housing opportunities (see, for example, Province of Ontario, 2011, 2016; City of Toronto, 2018). The vulnerability of renters is further exacerbated by the relatively low penetration of renters property insurance coverage in Canada (Insurance Canada, 2018). Social vulnerability in the context of urban and basement flooding is increasingly considered in urban flood management strategy (see, for example, City of Toronto, 2019). Specifically, basement flood mitigation projects in the City of Toronto will consider the Ontario Marginalization Index as part of its criteria for selecting priority risk reduction work (Toronto Water, 2020). With respect to property damage, exposure to basement flood damages is expected to increase as basements are increasingly used as additional living spaces within homes, containing expensive property vulnerable to damages from flooding (Friedland et al., 2014).

Basement flooding, particularly flooding associated with backing up of sanitary sewer systems-which introduces raw, untreated sanitary sewage into homes-presents health risks to household occupants. Public health units across Canada have identified sewer backup related basement flooding as a health risk that should be carefully managed after a flood event (Canadian Standards Association, 2018; Government of Manitoba, 2019; City of Vancouver, 2020; Peterborough Public Health, n.d.; York Region, n.d.).

Aside from the above financial, social and health impacts of flood, flooded households also experience loss of irreplaceable and sentimental items (e.g., photos, mementos stored in basements, etc.), and must also navigate potentially stressful and resource intensive rebuild processes. Further, many residents who occupy households with flood histories, or where households are located in communities, subdivisions, or postal codes considered to be at high risk of flooding, may experience changes in insurance premiums, deductibles, sub-limits or availability.

In many instances, urban and basement flood risk reduction requires application of interventions on both the "privateside" and the "public-side" of the property line. Municipalities typically have greater control and authority to manage "publicside" risk factors, including addressing inflow/infiltration (I/I) in of wastewater systems located in road right-of-ways and on municipally-controlled property. A significant proportion of I/I, however, and numerous urban flood risk factors, must be addressed on the private-side of the property line (see Robinson et al., 2019; Robinson and Sandink, 2021). Privateproperty factors that contribute to flood risk include I/I (e.g., inflow from downspout and foundation drain connections to sanitary and combined sewers), and various lot grading and drainage factors that may exacerbate flood risk and contribute to $\mathrm{I} / \mathrm{I}$.

There are numerous interventions applied on the private side that control flood risk for both individual properties and subdivisions/communities (or sewersheds). These measures have been formally documented in local, provincial and national guidelines (specifically, Canadian Standards Association, 2018), as well as numerous localscale/municipal basement flood education and engagement programs focused on residential flood risk reduction and private-side I/I management.

Considering the role of the private-side and households in reducing urban flood risk, this review paper explores the interrelated factors that affect the risk of basement flooding and explores the challenges and opportunities associated with the adoption and success of private-side flood mitigation approaches. This paper contains examples predominantly from a Canadian perspective; however, flood damage from pluvial events is an intensifying concern in urban environments around the world. Occurrences of pluvial flooding in urban environments share many similarities related to both causes and impacts, including the influence of drainage features and land-use, type of municipal infrastructure and stormwater management measures (Zhu and Chen, 2017; Mobini et al., 2020; Pagliacci et al., 2020). Municipalities and local sewer utility providers across North America also face challenges associated with inflow/infiltration (I/I) into sewer systems, and similar to basement flooding, programs have been developed across North America to encourage household participation in I/I reduction (see, for example, East Bay Municipal Urban District, (n.d.); City of Chicago, 2021). Furthermore, the potential effects of climate change and changing environmental conditions on flooding events threatens to exacerbate urban flood risk worldwide (Miller and Hutchins, 2017; Skougaard Kaspersen et al., 2017), requiring adaptation and further lot-scale mitigation to protect property from water damage (see, e.g., Leandro et al., 2020). The examples and challenges faced in Canada and presented in this paper have important significance and relation to those 
TABLE 1 | Major urban/basement flood insurance loss catastrophes in Canada, 2009-2020.

\author{
Event location and date, insured loss (2019 CAD, if Details \\ published) \\ Peterborough, ON, July 15, 2004 \\ Insured loss: \$113M \\ Toronto/GTA, ON, August 19, 2005 \\ Insured loss: \$795 M \\ Hamilton, Ottawa, ON (July 2012) \\ Insured loss: \$104 M \\ Toronto, ON, July 8, 2013 \\ Insured loss: \$1.024 B \\ GTA, ON, August 2014 \\ Insured loss: $\$ 84 \mathrm{M}$ \\ Saskatoon, SK, to Thunder Bay, ON, June 2016 \\ Insured loss: $\$ 40 \mathrm{M}$ \\ Estevan, SK, to Edmonton, AB, July 8-11, 2016 \\ Insured loss: \$59M \\ Windsor/Tecumseh, ON, September 28, 2016 \\ Insured loss: \$165 M \\ Southern ON and QC, April 5-7, 2017 \\ Insured Loss: \$116 M \\ Windsor/Tecumseh/Essex, ON, August 28-29, 2017 \\ Insured loss: \$177 M \\ ON/QC, October 2017 \\ $\sim 80 \mathrm{~mm}$ in $1 \mathrm{~h}, \sim 260 \mathrm{~mm}$ in $24 \mathrm{~h}$ \\ $132 \mathrm{~mm}$ in $2 \mathrm{~h}, 12 \mathrm{~h}$ accumulation of $149 \mathrm{~mm}$ (Toronto/North York) \\ $116-140 \mathrm{~mm}$ in $3 \mathrm{~h}$ in Hamilton area \\ $102 \mathrm{~mm}$ in $2 \mathrm{~h}, 6 \mathrm{~h}$ accumulation of $126 \mathrm{~mm}$ (Toronto/Pearson International Airport) \\ 150-200 mm in Burlington \\ $50 \mathrm{~mm}$ (up to $90 \mathrm{~mm}$ total) in $3 \mathrm{~h}$ (Thunder Bay, ON), $44 \mathrm{~mm}$ (Estevan, SK), $140 \mathrm{~mm}, 303$ \\ mm/h (West Hawk Lake, MB), 104 mm (Killarney, MB), 60 mm (Grandview, MB) \\ $\sim 130 \mathrm{~mm}$ in $2 \mathrm{~h}$ (Estevan, SK), $49 \mathrm{~mm}$ (Clearwater, MB), $86 \mathrm{~mm}$ (Lloydminster, SK), $89 \mathrm{~mm}$ \\ (Yorktown, SK area) \\ $195 \mathrm{~mm}$ (total), 100-110 $\mathrm{mm}$ in $5 \mathrm{~h}$ in Tecumseh, 115-230 mm in Windsor (24 h) \\ $\sim 80 \%$ of insured losses attributed to residential sewer backup/water damage \\ 30-40 mm (parts of S. ON/QC, April 4), 50-85 mm (parts of S. ON/QC, April 5-7), \\ $70-85 \mathrm{~mm}$ in Montreal \\ $290 \mathrm{~mm}$ in LaSalle, $+220 \mathrm{~mm}$ in Windsor, $190 \mathrm{~mm}$ in Essex \\ $\sim 70 \%$ of insured losses attributed to residential sewer backup/water damage. \\ Remnants of Tropical Storm Phillipe (112 mm in Ottawa, 74 mm in Kingston)
}

Insured loss: \$104M

Eastern Canada Winter Flooding, January 2018

S. ON and QC flooding, February 2018

Toronto SDHI flooding, August 2018

QC and Maritimes flooding and wind, January 2019

ON and QC, early February thaw, 2019

Southern ON and QC snowmelt and rain, March 2019

Eastern Canada flooding, March 2019.

ON, QC, and NB spring flooding, April-May 2019

Insured loss: \$272 M

Eastern Canada rain and windstorm, October-November

2019

Insured loss: \$256 M

ON and QC winter storm and flooding, January 2020.

Max rain: $127.5 \mathrm{~mm}$, Mechanic Settlement, NB. Losses also associated with high wind.

Max rain: $76 \mathrm{~mm}$, Lucknow, ON. Additional losses due to freezing rain.

Max rain: $72 \mathrm{~mm}$

Losses also attributed to freezing rain and wind.

Water and freezing rain related losses.

Losses attributed to snowmelt, rain and high wind.

Max rain: $62.2 \mathrm{~mm}$, Duncan Cove, NS.

Losses attributed to flood and high wind.

Max rainfall: $109 \mathrm{~mm}$, Stratford, QC. Losses also attributed to high wind and snow.

Max rainfall $82 \mathrm{~mm}$, Wellesley, ON. Losses also associated with freezing rain and high wind.

Sources: Catastrophe Indices Quantification Inc. (2020), City of Windsor (2017), Environment and Climate Change Canada (2017), Worsely (2005), and Town of Tecumseh (2016).

faced globally. This review article will enable the proposition of recommendations for the adoption and management of private-side technologies or approaches and identify areas of future research urgently needed to lead to improved privateside mitigation approaches and adoption to reduce the risk of basement flooding.

\section{FLOOD RISK FACTORS AND MITIGATION APPROACHES}

This section describes the different mechanisms by which basements can flood, identifies the varied sociopolitical, environmental, and infrastructure factors that influencing basement flooding and presents an overview of the private-side mitigation approaches or technologies that can be applied to reduce urban flood risk.

\section{Basement Flood Mechanisms Overland}

Overland flooding results from flow, accumulation, and ponding of rainwater and/or snowmelt in areas adjacent to buildings. In the example provided in Figure 1, the stormwater system has become overwhelmed, and water is flowing in an uncontrolled manner over the surface, and entering homes through abovegrade openings. Water is also entering the backfill area directly adjacent to the exterior of the foundation wall, and seeping into the basement. The below example also illustrates how overland flooding contributes to inflow/infiltration and sewer backup risk, 


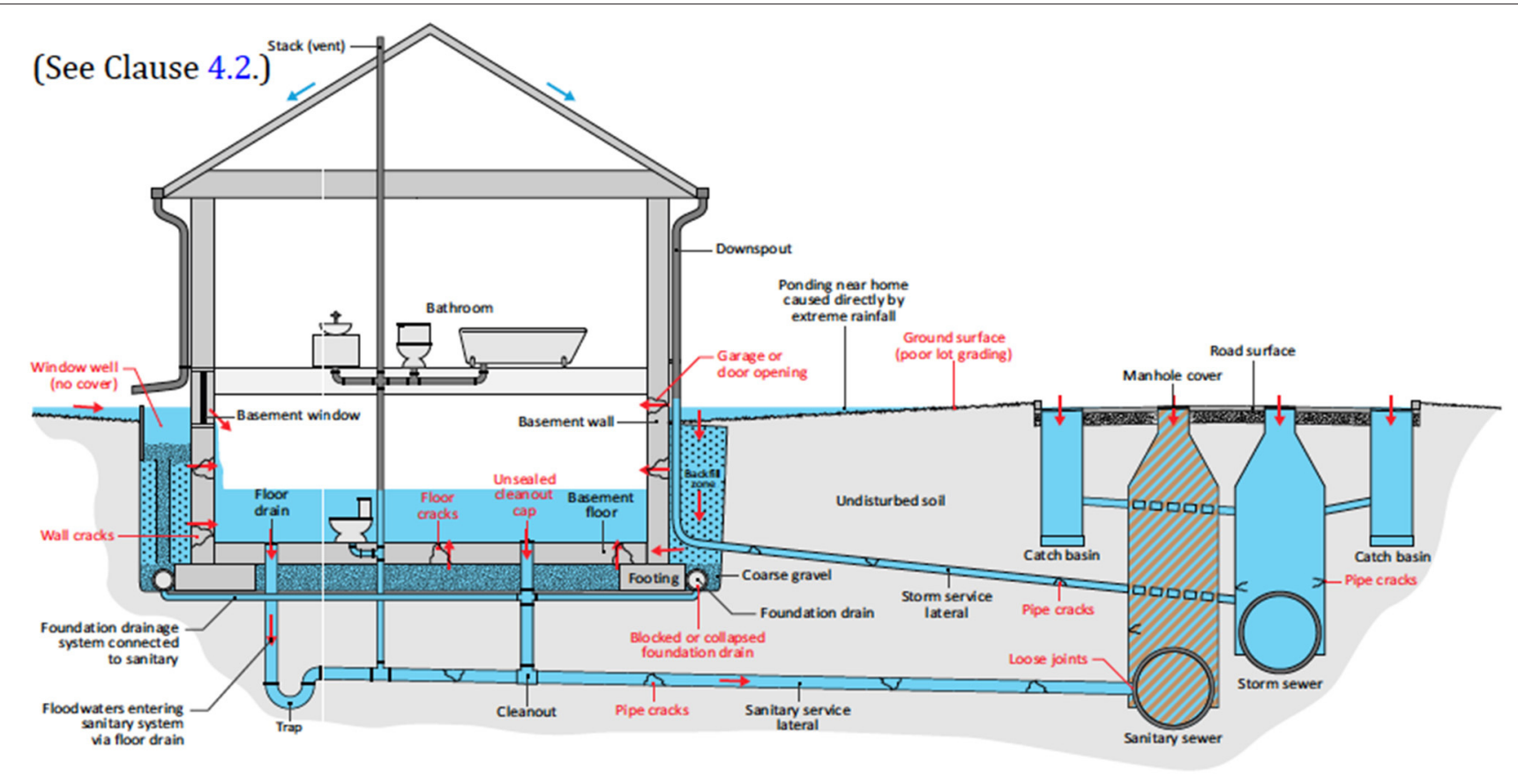

FIGURE 1 | Overland (stormwater) flooding (Canadian Standards Association, 2018-adapted from Sandink, 2009).

as surface water that has entered the basement is draining into the sanitary sewer via the floor drain.

\section{Infiltration (or Seepage)}

Infiltration flooding may be associated with groundwater, surface water, and sewer backup. In the example provided in Figure 2, surface water has collected in the backfill area adjacent to the basement wall, and is percolating into the porous backfill zone, resulting in seepage of water through cracks in the foundation wall and contributing to excess flows in the home's foundation drainage system. Infiltration flooding may be associated with snowmelt events, prolonged rainfall events, and groundwater levels that have exceeded the lowest level of the basement floor. Buildings with no foundation drainage systems, or where foundation drainage systems are compromised, are particularly vulnerable to infiltration flooding (Canadian Standards Association, 2018).

Further, where foundation drains are connected to municipal sewer networks, surcharge, and backup of the systems may result in infiltration flooding in homes. In the example in Figure 2, the foundation drainage system is connected by gravity to the municipal storm sewer system. The storm sewer system has become surcharged, forcing water into the foundation drainage system, and causing infiltration flooding into the home.

\section{Sewer Backup}

Sewer backup flooding is associated with surcharging storm, wastewater, combined or "third pipe" (e.g., foundation drain collector pipe) sewers. Figure 3 illustrates simultaneous flooding associated with surcharged storm and wastewater sewer systems. In this example, the surcharged sanitary sewer is backing up into the home, with flood waters entering the home via basement plumbing fixtures. Stormwater is backing up into the foundation drainage system, forcing water into the bedding beneath the basement floor slab and the backfill zone, resulting in infiltration flooding into the home.

\section{Additional Causes}

Aside from the above mechanisms, a series of lot-level drainage and plumbing failures may result in basement flooding (Canadian Standards Association, 2018). For example, failure of sump pump systems, associated with mechanical failures of the pump, interruption in electrical supply, inadequate sizing of the pump or pit, is a common cause of insured loss associated with basement flooding (Sandink et al., 2020). Failure of sewer lateral connections due to partial or complete blockages (associated with fats-oils-grease, non-dispersible materials, root penetration, poor installation, etc.), improper pipe grading, or other structural defects can also contribute to flood occurrence at the property scale (Canadian Standards Association, 2018; Robinson et al., 2019; Robinson and Sandink, 2021).

\section{Flood Risk and Influencing Factors}

Numerous factors affect the risk of flooding of an individual home, including socio-political, environmental, and infrastructure factors (see Table 2). Consideration of all of these factors and their inter-relationships is needed to ensure successful design and implementation of mitigation methods to reduce the risk of basement flooding and to identify and prioritize private-side strategies based on site-specific conditions. 

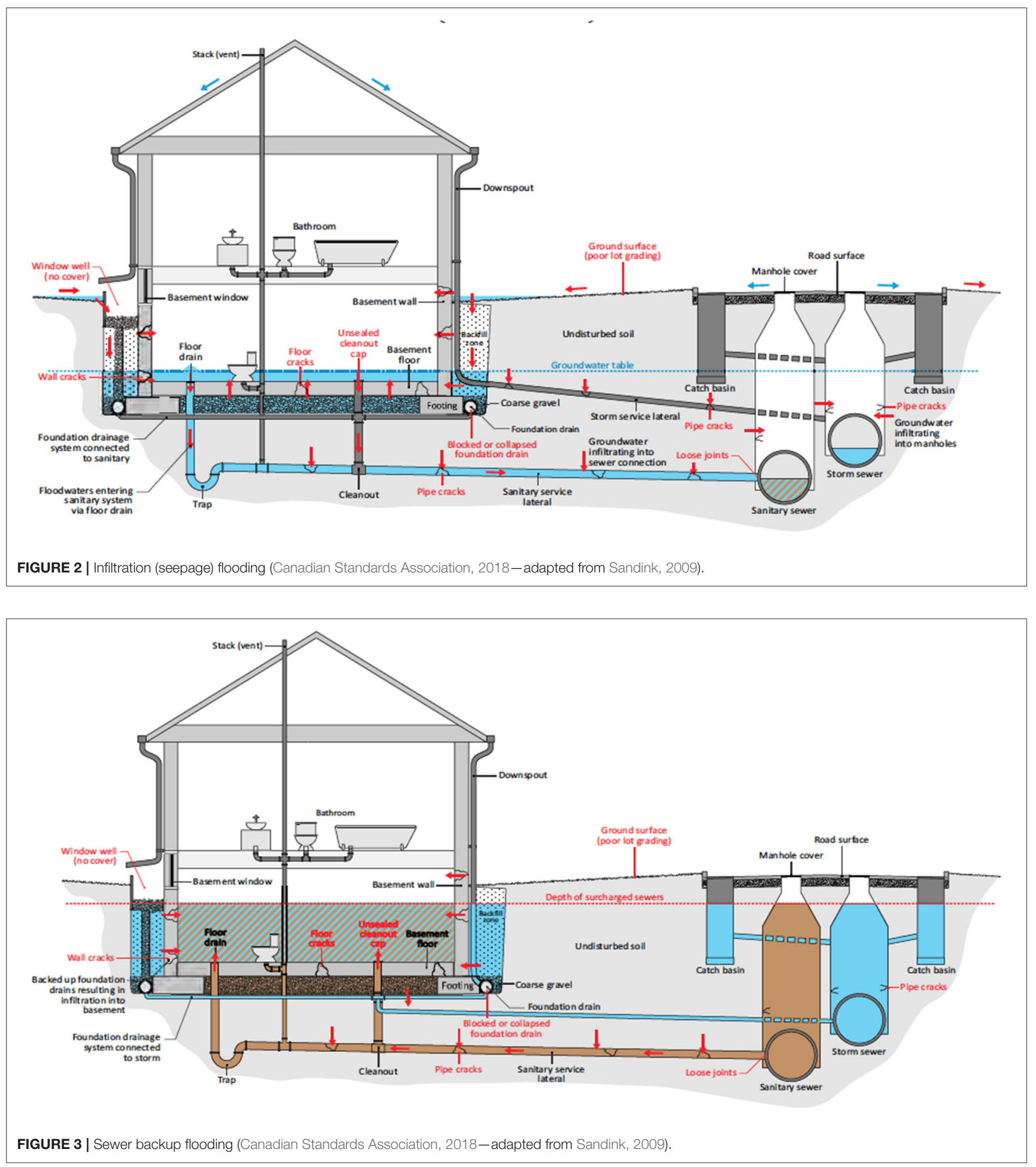

\section{Socio-Political Factors}

Socio-political factors, including public perceptions and attitudes and governance, can affect the risk of flooding for a particular home. These factors can affect the public's and industry's approach to the design, construction and adoption of privateside flood mitigation strategies and influence the vulnerability of individual homes to residential basement flooding. This can include citizen participation in hazard mitigation policy 
TABLE 2 | Factors affecting residential flood risk.

\begin{tabular}{|c|c|c|c|c|c|}
\hline \multicolumn{2}{|c|}{ Socio-political } & \multicolumn{2}{|c|}{ Environmental } & \multicolumn{2}{|c|}{ Infrastructure } \\
\hline Social & Governance & $\begin{array}{l}\text { Hydro-meteorological } \\
\text { conditions }\end{array}$ & $\begin{array}{l}\text { Watershed } \\
\text { characteristics }\end{array}$ & Municipal infrastructure & $\begin{array}{l}\text { Private-side } \\
\text { infrastructure }\end{array}$ \\
\hline $\begin{array}{l}\text { Public awareness and } \\
\text { perception }\end{array}$ & $\begin{array}{l}\text { Building and plumbing } \\
\text { code requirements }\end{array}$ & Climate & $\begin{array}{l}\text { Topography, soil and } \\
\text { vegetation }\end{array}$ & Urban drainage systems & Sewer lateral condition \\
\hline Citizen participation & Planning policies & Hydrology & Land-use and land-cover & $\begin{array}{l}\text { Stormwater and } \\
\text { wastewater management } \\
\text { systems }\end{array}$ & $\begin{array}{l}\text { Basement flood mitigation } \\
\text { technologies }\end{array}$ \\
\hline $\begin{array}{l}\text { Water conservation, } \\
\text { occupant behavior }\end{array}$ & $\begin{array}{l}\text { By-law, regulation, } \\
\text { construction code } \\
\text { enforcement and inspection } \\
\text { authority and capabilities }\end{array}$ & Temperature & $\begin{array}{l}\text { Surface and groundwater } \\
\text { features }\end{array}$ & Street storage & Lot drainage characteristics \\
\hline
\end{tabular}

(Oulahen and Doberstein, 2012) which engages the public in the area of flood risk and vulnerability and the adoption of technologies to reduce this risk. This aids in developing an awareness for homeowners of the infrastructure present in the home and the requirements for homeowner maintenance (Sandink, 2011; Owusu et al., 2015).

Governance factors, including national and provincial building and plumbing code requirements, interpretation and enforcement, can impact the decisions to install flood mitigation approaches. There exist inconsistencies regarding the interpretation and enforcement of private-side flood mitigation technologies across Canada (Sandink, 2013). As a result of these inconsistencies, flood risk and vulnerability can vary substantially across the country. By-law enforcement and inspection authority and capabilities can further affect the risk of flooding of residential basements, and planning policies that influence housing density and use of basements as living spaces can impact the severity of economic damages due to occurrences of basement flooding.

There is a critical importance to engage with the public on flood risk and vulnerability in order to improve flood risk communication and response to flooding events (Sampson et al., 2019). Public education has improved adoption of privateside flood mitigation measures and research has shown that increased awareness of private-side measures can result in reduced economic impact due to flooding (Owusu et al., 2015); however, challenges exist with respect to effectively engaging the public in flood risk reduction options (Grothmann and Reusswig, 2006; Terpstra et al., 2009; Meyer et al., 2014).

\section{Environmental Factors}

Environmental factors that affect the risk of flooding for a region or home include hydro-meteorological factors and watershed characteristics. Hydrometeorology factors, including climate and hydrology, are key drivers affecting the magnitude and frequency of flooding events experienced in the watershed. Watershed characteristics such as topography, land use and land cover and surface water and groundwater conditions are important features that affect the hydrological processes influencing the flood regime for a region.
Land use and land cover in a given watershed influence flooding and the related losses and damages (Brody et al., 2014). In particular, urbanization and the spatial distribution of impervious cover across a watershed can greatly increase the flood potential for a given watershed (Sheng and Wilson, 2009). According to Ahn and Merwade (2016) watershed morphometry, watershed slope and land use are among the most significant watershed factors affecting cases of extreme and severe flooding events.

Rising water tables can lead to the presence of groundwater near residential foundations which can increase basement flood potential and damage to the foundation (Soren, 1976). This was recently observed in the Alberta 2013 floods where increases in the river stage lead to rising groundwater levels in riverconnected aquifers, leading to occurrences of infiltration flooding into basements (Abboud et al., 2018). Changes in groundwater abstraction rates and practices have also led to documented cases of rising groundwater levels and concern regarding the impact on infrastructure (Wilkinson, 1985). In comparison with riverine flooding, infiltration flooding due to rising groundwater levels have been shown to result in different damage characteristics to basements and require different models to assess losses (Kreibich and Thieken, 2008).

Hydrology-related factors such as precipitation, temperature, and climate are important considerations related to the sensitivity to flooding for a given region. For urban areas the spatial and temporal variability of the rainfall patterns are important factors in determining the hydrological response to flooding events in the watershed (Yang et al., 2016). The effect of climate change may result in changes to precipitation patterns and magnitudes for regions across Canada, and the urban environment is particularly sensitive to such changes. Small changes in precipitation may result in dramatic increases in flows in urban drainage systems, increasing the possibility of surcharging sewers and flooded manholes (Nie et al., 2009).

\section{Infrastructure Factors}

Infrastructure factors, including large-scale municipal infrastructure and building- or private-side technologies and/or approaches for flood mitigation, can affect flood risk. Municipal factors, such as the nature and conditions of the sewer 
system, urban development patterns and large-scale stormwater management infrastructure are important factors that can contribute to the risk of basement flooding.

Increased vulnerability to basement flooding has been documented for homes connected to a combined sewer system rather than a separate sewer system (Mobini et al., 2020). Excessive flows in combined sewer systems can result in repeated occurrences of sewer surcharge and necessitate the need for reservoirs to store excess sewage during large rainfall events to prevent occurrences of sewer back-up resulting in basement flooding (Bergman and Kapadia, 1988). There is a need for dual drainage modeling due to urban flooding resulting from surcharge sewers and development of increased knowledge of the interaction between surface flows and sewer network dynamics as well as increased capabilities to model surface flow pathways (Schmitt et al., 2004; Leandro et al., 2009; Seyoum et al., 2012). Basements can also flood from excessive rainfall-derived infiltration and inflow (RDII) that results from surcharging sewers which can be due to the age or deterioration of municipal infrastructure and contributions from sources such as surface runoff and residential foundation drains (Brown and Hill, 2003). In many regions of Canada, "partially separated" or "semi-combined" systems, where private side downspouts and foundation drainage systems are discharged to municipal-side separated sanitary sewer systems, are also considered vulnerable to sanitary sewer surcharge events, resulting in regional sewer backup flooding (see Metro Vancouver Liquid Waste Services Department, 2016; City of Ottawa, 2021; Utilities Kingston, 2021).

The presence of stormwater management infrastructure, such as stormwater detention ponds, can greatly alter the hydrologic response to flood events and slow down the transmission of runoff (Yang et al., 2016). In addition to traditional stormwater management infrastructure, green infrastructure or low impact development measures, such as green roofs and vegetated swales, have potential to reducing surface flooding, particularly if these measures are strategically implemented within the watershed (Haghighatafshar et al., 2018); however, questions remain regarding their efficiency in reducing occurrences of basement flooding.

Numerous lot-level factors (or characteristics) can result in increased risk or vulnerability for an individual home to basement flooding from overland, infiltration, or sewer surcharge mechanisms. Local surface conditions such as street gradients, sidewalks and curb heights and lot grading (Schmitt et al., 2004) and the presence of the above-mentioned green infrastructure or low impact development measures to divert or temporarily store stormwater on the individual lot (Carr et al., 2001) can influence the risk of flooding from overland flow. The risk of flooding from infiltration mechanisms can be affected by connections between the foundation drainage system and the sanitary sewer system (TenBroek et al., 2002; Ladson and Tilleard, 2013; Chambers, 2014), and drainage characteristics in the proximity of the perimeter of the home and protection of the foundation from moisture (Swinton and Kesik, 2008). Characteristics of the sewer lateral (e.g., slope, age, condition, presence of obstructions such as root blockages, etc.) can affect the sensitivity of a home to basement flooding from sewer surcharge mechanisms.

Private-side infrastructure or approaches can be implemented in residential buildings to reduce the risk of flooding for individual homes, including backwater valves to protect against sewer surcharge, appropriate lot grading and drainage, and foundation drainage systems (e.g., weeping tile systems) to protect the home from infiltration flooding. Proper installation techniques and regular homeowner maintenance are necessary to ensure private-side infrastructure such as backwater valves perform effectively (Irwin et al., 2018).

\section{Private-Side Flood Mitigation Measures}

Broadly, basement flood risk reduction on the private-side of the property line can be classified as either behavioral or physical. Behavioral measures are those that concern the actions and behaviors of household members to manage flood risk, for example actively seeking out information concerning flood risk in their community, informing local authorities of their flood experience, and having plumbing inspections conducted in homes. These interventions are intended to ensure that households access appropriate information that reflects details concerning their municipality, subdivision, lot and home that have significant implications concerning selection of appropriate physical mitigation interventions.

Physical interventions include those that result in changing of plumbing and drainage characteristics of buildings and properties to reduce flood risk (Sandink, 2016). Details concerning private-side mitigation of basement flood risk are further outlined in CSA Z800-18 (Canadian Standards Association, 2018), and are summarized in Table 3. Though several interventions may be targeted specifically at limiting risk of overland flood waters entering buildings, by keeping water out of basements-and thereby keeping water from draining into flood drains connected to sanctuary sewers-these interventions may also contribute to reduction of I/I.

\section{CHALLENGES FOR ADOPTION AND SUCCESS OF FLOOD MITIGATION MEASURES}

Numerous challenges exist that affect the successful adoption and continued performance of flood mitigation measures. This section discusses several of these challenges, including public awareness and engagement, the difficulty in identifying the cause of a flood at the building scale, uncertainty in the efficacy of flood mitigation measures, jurisdictional issues for the implementation of these measures and maintenance issues to ensure continued performance of private-side mitigation measures.

\section{Public Awareness and Engagement}

Effective engagement of households in basement flood risk reduction is an ongoing challenge. Municipalities across Canada have developed financial subsidy programs aimed at increasing uptake of private-side basement flood interventions. Financial resources made available to households to engage in risk 
TABLE 3 | Private-side basement flood risk interventions (physical) (Sandink, 2016; Canadian Standards Association, 2018).

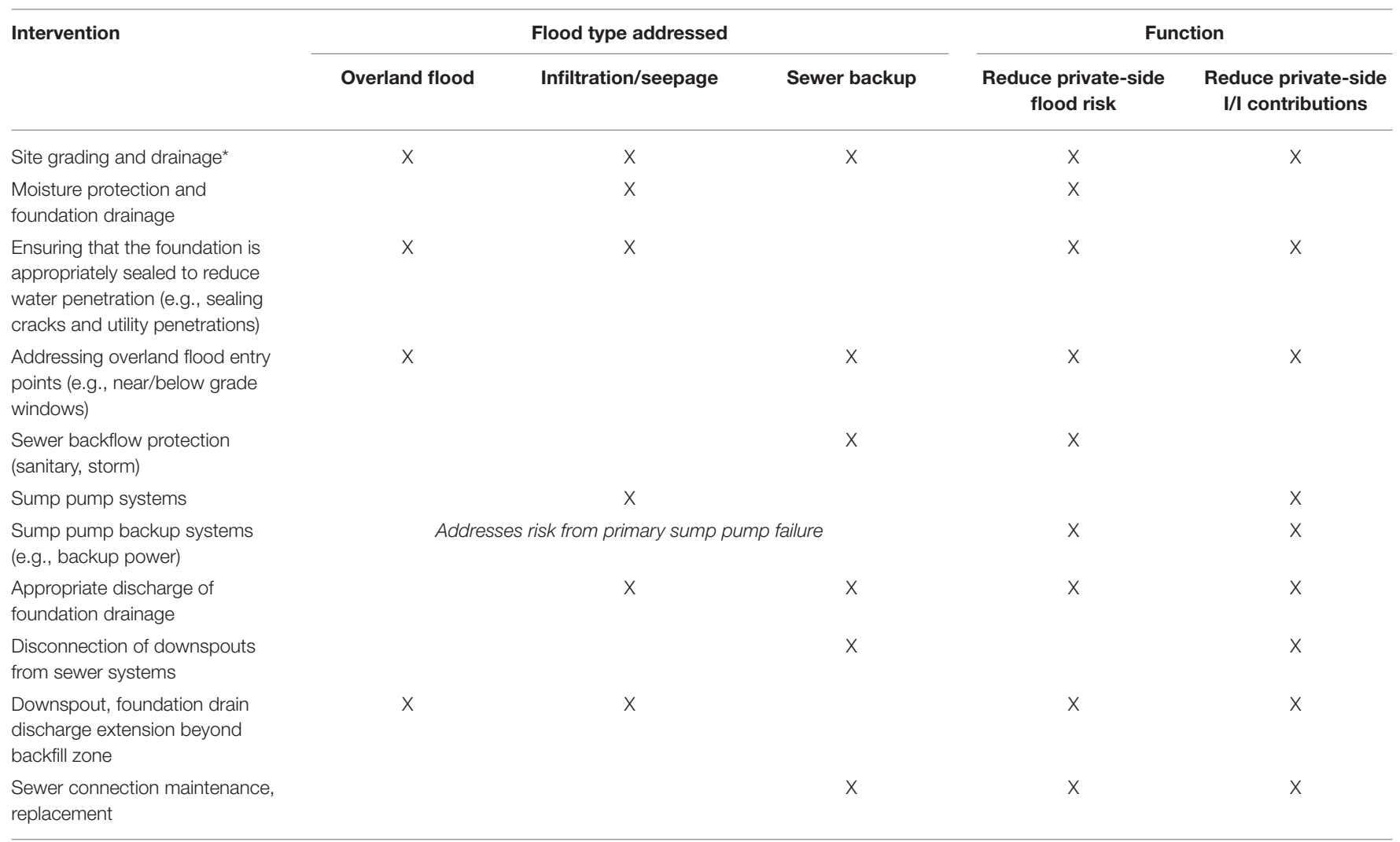

*Includes and site grading and drainage feature that serves to reduce risk, such as restricting use of reverse slope driveways and exterior basement stairwells.

reduction activity are dependent on the municipality issuing the program; however, the programs emphasize mitigation of risk associated with sanitary sewer surcharge (Sandink, 2013; Institute for Catastrophic Loss Reduction, 2017). Further, preliminary interviews conducted with municipal staff managing subsidy programs in 10 Canadian communities have indicated that uptake programs is often low (Institute for Catastrophic Loss Reduction, 2017), reflecting previous findings in the disaster risk perception and behavior literature (Martin et al., 2007; Jassempour et al., 2014; Meyer et al., 2014; Thomas et al., 2018; Botzen et al., 2019).

Several flood mitigation measures concern buried systems, including buried sewer connections, drainage pipes located below concrete basement floor slabs, and foundation drainage systems. The condition of these systems cannot be easily assessed, and conceptualizing some flood mitigation measures (e.g., disconnecting foundation drainage systems from sanctuary sewers) adds complexity to homeowner planning for risk reduction. Flood mitigation is also a response to low probability, high consequence events. Unlike energy use reduction options at the household level, which provide potential immediate and ongoing benefits to the household in the form of reduced energy costs, the performance of flood mitigation measures is dependent on the occurrence of extreme rainfall events that exceed local design capacities for stormwater and wastewater systems.
A further barrier to implementation is that critical I/I reduction interventions-including disconnecting foundation drainage systems, disconnecting downspouts from municipal sanitary (or combined) sewer systems, and repairing leaking sewer laterals-may not serve to directly protect the household that adopts the intervention. For example, households that have not experienced flooding or are at low risk of flood may still be requested to mitigate their home's contribution of excess flow to the sanitary system to protect downstream residences (e.g., downspout and foundation drain disconnection from sanitary sewers). The process of installing these I/I management interventions, while serving to contribute to community level (or sewershed) risk reduction, may introduce significant inconvenience to a household, while offering limited direct benefit. Further, as flood issues, including sewer backup, result from the failure of built infrastructure (e.g., sanitary sewers), there may exist the perception that responsibility for mitigation lies with the municipality or local authority responsible for drainage and wastewater, and that it is not the responsibility of households to engage in flood risk reduction (Sandink, 2011).

While the cost to install most flood risk reduction measures in new construction is relatively low, retrofitting of flood mitigation measures can be highly costly for households. While municipal subsidy programs may provide partial assistance for expensive mitigation interventions including backwater valve and sump 
pump systems, additional issues may arise during installation that can drive up costs substantially. For example, poorly graded building drains located beneath basement floors may have to be re-graded, cast-iron pipes may have to be replaced, and sanitary sewer connections cleared of debris and blockages before backwater valves can perform properly (see Sandink, 2017). Flood risk reduction measures will also require maintenance, including routine checks of key components and regular cleaning (Canadian Standards Association, 2018).

\section{Uncertain Efficacy of Private-Side Interventions}

Two primary factors that limit efficacy of flood risk reduction measures include:

1. Clear definition and treatment of the flood types that the building is exposed to, and

2. Efficacy of flood mitigation intervention methods themselves, resulting from product or intervention design, installation, and/or maintenance issues.

Concerning Factor 1, as discussed above, basement flood causes are interdependent. For example, overland flooding associated with short-duration high-intensity rainfall events can contribute to inflow/infiltration (and therefore sewer backup risk), sewers may back-up into storm and/or sanitary sewer connections, and sewer backup, overland flood and infiltration flood may occur simultaneously. Further, if homeowners are not present to observe water entering homes via the surface, through plumbing fixtures, sump pits, and or foundation walls, it will be difficult to determine how flood waters entered the home.

Some types of flood may be indistinguishable to a resident; for example, infiltration flooding resulting from overloaded foundation drainage systems (Table 4 Type A) and infiltration flooding associated with backing up of storm sewer systems into foundation drains (Table 4 Type B) may appear to the homeowner as floodwaters seeping into the basement through floors and walls. Mitigation for these two flood types, however, require drastically different intervention options (Table 4). Similar to the example provided in Table 4, sanitary sewer backup may be caused by overwhelmed municipalside sewers, and/or from compromised private-side sanitary sewer connections (Canadian Standards Association, 2018). The interrelated nature of flood causes results in difficulty in diagnosing flood risk and intervention solutions by all stakeholders involved in flood risk reduction, from homeowners to insurance and municipal infrastructure professionals.

Concerning Factor 2, there is limited information and evidence available about the long-term efficacy of basement flood protection measures, notably active and passive systems intended to protect the home directly. Backwater valves, sump pumps, and backup power systems require maintenance and proper installation for effective long-term operation. Further, construction code requirements may not reflect the installation needs of these systems. For example, backwater valve manufacturer instructions indicate that a minimum $2 \%$ slope should be applied for proper function of a popular backwater valve product (ML 4963-Mainline Backwater Valves, 2013), and a steeper grade is preferred. Local construction code interpretation, however, may permit sanitary building sewer slopes of only 1\% (Robinson et al., 2019). Misalignment of basic code requirements and installation requirements for flood mitigation interventions present risk associated with long-term performance of these devices.

\section{Municipal Programs Emphasize I/I and Sewer Backup Protection}

Municipal programs emphasize controlling inflow/infiltration and flood risk associated with sewer backup, and promote interventions including backwater valves, foundation drain disconnections, sump pump installations, and downspout disconnections. These programs therefore do not typically assist homeowners with multiple/complex flood causes, including combinations of sewer backup, infiltration and overland flood (Institute for Catastrophic Loss Reduction, 2017).

\section{Varied Levels of Success at Engaging Households in Risk Reduction}

Table 5 outlines common methods applied to encourage households to participate in flood risk reduction. These methods range from provision of communication information to households, to generous financial assistance for private-side flood risk reduction work, enforcement of local bylaws concerning sanitary sewer use, and interpretations of provincial construction code wordings to require flood mitigation interventions.

With respect to on-the-ground implementation of flood mitigation options at the private-side of the property line, success of these programs is highly varied. While enforcement of sewerrelated by-laws and code provisions in new construction is highly effective, managing existing residences is difficult. For example, enforcement of local sewer use bylaws, which, for example, may prohibit connection of foundation drainage, sump pump systems, and/or downspouts to sanitary sewer systems, may require entering of homes, CCTV inspections of laterals, dye testing, smoke testing, etc., and require voluntary compliance of residents to access properties and homes for these purposes. Lateral certification programs and time of sale requirements for lateral inspections have been explored in Canada (see Metro Vancouver, 2008), as have requirements for inspections of laterals when significant renovations or redevelopments occur on the private-side of the property line (for example, City of Surrey-see Kyriazis et al., 2017; Robinson and Sandink, 2021). These programs, however, have yet to be widely implemented across Canada.

\section{Jurisdictional Challenges}

Many factors driving flood risk are located on the private-side of the property line, and are under the control of homeowners and households (Figure 4). It is therefore imperative that private property owners and households become engaged in risk reduction.

Extraneous connections to sanitary sewers (including downspout and foundation drainage connections to sanitary sewers), and leaking sanitary sewer laterals are significant 
TABLE 4 | Interventions for two types of foundation drain system failures.

\begin{tabular}{llll}
\hline Flood type & Description & Appears to homeowner as & Possible intervention \\
\hline A & $\begin{array}{l}\text { Overloaded foundation drainage } \\
\text { system, seepage into basement via }\end{array}$ & $\begin{array}{l}\text { Water seeping into basement via } \\
\text { cracks, joints in basement floor and }\end{array}$ & $\begin{array}{l}\text { Improve surface drainage, cap backfill } \\
\text { area, maintain/repair foundation } \\
\text { drainage system }\end{array}$ \\
infiltration originating at the lot level & walls & Protect home from storm sewer \\
B & Sackstem backflow (e.g., disconnect \\
& Backing up of storm sewer system & & foundation drainage system, add \\
& into foundation drainage, where & & sump pump; provide backwater \\
foundation drainage drains by gravity & proction on private-side storm & sewer connection)
\end{tabular}

TABLE 5 | Common approaches for engaging households and observations.

\begin{tabular}{|c|c|c|}
\hline Engagement method & Examples & Observations \\
\hline Education programs & $\begin{array}{l}\text { Distribution/access to brochures, communications } \\
\text { materials, public meetings, websites }\end{array}$ & Relationship to uptake is unclear, unmonitored \\
\hline $\begin{array}{l}\text { Local "mandatory" } \\
\text { approaches (existing } \\
\text { construction) }\end{array}$ & $\begin{array}{l}\text { Enforcement of local sewer use and downspout } \\
\text { disconnection bylaws } \\
\text { Lateral certification programs } \\
\text { Lateral inspections at time of } \\
\text { redevelopment/significant renovation }\end{array}$ & $\begin{array}{l}\text { Strict bylaw enforcement for existing residences is } \\
\text { often impractical, politically unpopular } \\
\text { Lateral inspections/replacement at time of } \\
\text { redevelopment/significant renovation have been } \\
\text { tested and applied in only a small number of cases } \\
\text { in Canada. }\end{array}$ \\
\hline $\begin{array}{l}\text { Local bylaws (outside } \\
\text { of construction code } \\
\text { and building services } \\
\text { department jurisdiction) }\end{array}$ & $\begin{array}{l}\text { Interpretation or enforcement of lot grading and } \\
\text { drainage bylaws in a manner that restricts use of } \\
\text { reverse slope driveways } \\
\text { Inclusion of wording in planning, zoning bylaws that } \\
\text { restrict use of reverse slope driveways }\end{array}$ & $\begin{array}{l}\text { Highly effective for new construction. Difficulties } \\
\text { exist with respect to enforcement and } \\
\text { implementation in existing neighborhoods, due to } \\
\text { cost, technical complexity and limited homeowner } \\
\text { involvement }\end{array}$ \\
\hline Insurance incentives & $\begin{array}{l}\text { Premiums, sub-limits on water damage/sewer } \\
\text { backup endorsements, deductibles, availability of } \\
\text { cover }\end{array}$ & $\begin{array}{l}\text { When applied to the water damage component of a } \\
\text { property insurance policy, incentives may not offer } \\
\text { significant offsetting of cost of installation of } \\
\text { mitigation measures } \\
\text { Interventions such as sub-limits and deductibles } \\
\text { may not be readily understandable by households }\end{array}$ \\
\hline $\begin{array}{l}\text { Direct financial } \\
\text { subsidies (insurance) }\end{array}$ & $\begin{array}{l}\text { Direct financial subsidy for mitigation interventions } \\
\text { following claim events }\end{array}$ & $\begin{array}{l}\text { Several large/national insurers are offering direct } \\
\text { incentives for mitigation following flood } \\
\text { events - uptake is varied; typically below } \\
\text { expectations }\end{array}$ \\
\hline
\end{tabular}

Sources: Kyriazis et al. (2017), Robinson and Sandink (2021), Robinson et al. (2019), and Sandink (2011, 2016).

contributors to inflow/infiltration (Robinson and Sandink, 2021). A survey conducted by the Water Environment Federation of 58 US agencies revealed that all but one agency considered I/I in sanitary sewer systems an issue. Further, 26 of these agencies provided estimates of private-side contributions to overall $\mathrm{I} / \mathrm{I}$, ranging from 7 to $80 \%$, with an average estimation that $24 \%$ is contributed through private-side sewer laterals (Water Environment Federation, 2006). Pearlman (2017) suggested that, in many municipalities, $40 \%$ of sewer system infiltration originated from the private-side of the property line. Nelson et al. (2005) identified that $55 \%$ of I/I in the municipal system originated from private-side of the property line, and Pawlowski et al. (2014) identified that $35 \%$ of I/I sources during SDHI rain events originated from residences, and that $98 \%$ of private-side I/I originated from laterals and downspouts in Columbus, Ohio. Reflecting private-side I/I contributions, the connection of foundation drains in partially separated/semi-combined sewer systems remains an ongoing important source of I/I in 


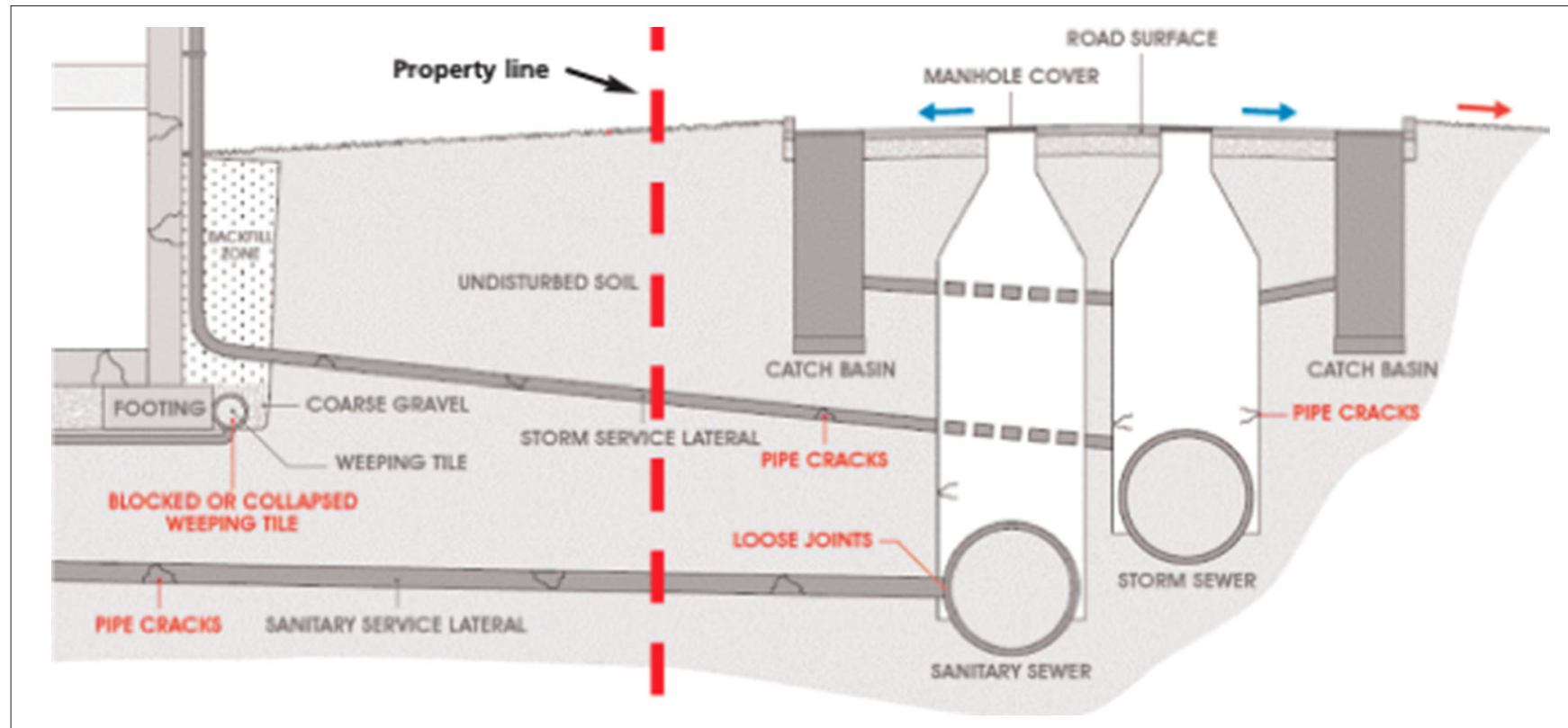

FIGURE 4 | Property line dividing private-side from municipal-side jurisdiction (Sandink, 2009).

regions across Canada (Metro Vancouver Liquid Waste Services Department, 2016; Canadian Standards Association, 2018; Peiying et al., 2019; Robinson and Sandink, 2021).

A further jurisdictional challenge is that numerous lot-grading and drainage issues that contribute to overland and infiltration flood risk (for example, settlement of backfill areas, reverse-slope driveways, poor grading that directs surface water toward the building), must be either partially or wholly managed on the private-side of the property line. Building plumbing and drainage components (sump pump systems, sewer backflow protection) are also installed and maintained on the private-side of the property line, and inside of the home where they cannot be easily inspected by municipal officials.

\section{Maintenance Issues}

Maintenance issues with respect to private-side flood mitigation measures have been gaining increased awareness in recent years. The effectiveness of private-side flood mitigation measures depends on regular and appropriate maintenance on the part of the home or building owner/operator. Maintenance ensures that the mitigation measures continue to perform as designed and protect the basement from water intrusion.

Backwater valves installed to protect the basement from sewer surcharge need to be regularly maintained by the homeowner by cleaning the valve of solids and debris that build up over time. Solid particles can settle and build-up within the main body of the valve. In particular, these solid particles can settle underneath the flap of the valve in some popular normallyopen valve models (Dusolt, 2019). The build-up of the solids in this location can inhibit the free movement of the flap within the valve, causing the valve to remain stuck in the open position during a surcharge event. Regular maintenance to clean the valve from any deposited solids and check the movement of the flap and its components (e.g., O-ring, floats) is required to ensure the valve performs as designed during a surcharge event. In addition, the condition of the sewer lateral downstream of the valve should also be regularly inspected to ensure that it is clear of any obstructions, such as tree roots.

Foundation drainage systems installed around the perimeter of the home's foundation also require regular maintenance by the homeowner. The drainage pipe can become overgrown with roots and other blockages (Horizon Engineering, 2020) which would inhibit or reduce the ability to transport water. Fine material from the surrounding soil can also enter the drainage pipe, leading to possible clogging of the openings along the pipe, and inhibiting the ability of groundwater from the surrounding subsurface to enter the drainage pipe. Regular inspection of the drainage pipe can ensure that the pipe is free from obstructions and any clogging from deposited material. Maintenance to ensure the drainage pipe is free from these obstructions can then be performed by a professional to ensure the foundation drainage system performs as designed. Homeowners should also regularly ensure that their sump pump is properly functioning, including any battery back-up for their sump pump (if present).

The condition of the ground surface on the lot is also an important aspect of homeowner maintenance to help protect the basement from water intrusion and flooding. This includes ensuring that lot grading directs water away from the foundation of the home and checking that the soil directly around the perimeter of the home is free from any local depressions 
where water could pool. Homeowners should also ensure that downspouts discharge at the required minimum distance from the foundation wall.

Lastly, proper communication with respect to the private-side flood mitigation measures located within the home is paramount, particularly at the time of sale to new homeowners. This includes the maintenance requirements, access and lifespan/condition of the flood mitigation measures.

\section{OPPORTUNITIES AND RECOMMENDATIONS FOR IMPROVED FLOOD PROTECTION}

This section discusses recent advances from the literature related to both structural flood mitigation strategies, such as private-side flood mitigation approaches or green infrastructure installations, and research into perception and behavior related to the uptake of disaster mitigation strategies at the household level. From this, a list of recommendations to reduce risk of urban pluvial flooding events is provided.

\section{Research Into Physical Flood Mitigation Strategies}

While research into prediction and impacts of flooding is prevalent in the literature, specific research into the vulnerability and impact of basement flooding is relatively limited. Several advances into the performance of catchment-scale and privateside flood mitigation strategies have been made as research into this topic has increased in recent years. Research has included both numerical and experimental approaches and has focused on the capabilities of green infrastructure (or low impact development) and lot drainage, sewer back-up and backwater valves, and infiltration flooding and foundation drainage systems.

\section{Influencing Factors on Occurrence and Magnitude of Urban Flooding Events}

Sörensen and Mobini (2017) utilized insurance claim data to gain greater insight into the influential characteristics that result in flooding. Considering specifically basement flooding due to overland, groundwater intrusion and infiltration (i.e., drainage system) flooding for a city in Sweden, these authors found that the intensity and spatial distribution of rainfall, type of drainage system, distance to main sewer systems and overland flow routes are amongst the most influential characteristics affecting urban flood risk.

White et al. (2013) applied numerical modeling tools to investigate conveyance capacity in combined sewer systems to evaluate the magnitude and location of occurrences of sewer surcharge into basements and surface flooding. Considering areas in the sewer network in Portland, Oregon where extensive occurrences of basement flooding have occurred, Dutt and Hemphill (2004) designed a toolbox for optimization and recommendation of basement flooding relief alternatives, including consideration of pipeline and sewer conveyance improvements, stormwater separation, residential downspout disconnection and green infrastructure measures. These authors applied a comprehensive approach that included field monitoring, hydraulic modeling and geospatial information systems software to evaluate the effectiveness of proposed improvements.

\section{Catchment-Scale (or Neighborhood-Scale) Green Infrastructure Installations}

Interest in the capabilities of green infrastructure installations to reduce runoff and minimize the risk of basement flooding has been growing in recent years. Flood damage observed in neighborhoods in an area of Sweden in response to an extreme precipitation event with an estimated return period between 50 and 200 years were compared by Sörensen and Emilsson (2019). These authors found that neighborhoods with bluegreen infrastructure (including stormwater detention ponds, green roofs, and swales) resulted in less damage compared to areas in the city having conventional stormwater management (i.e., combined or separate pipe networks). Steis Thorsby et al. (2020) applied numerical modeling tools to investigate the effectiveness of neighborhood-scale green infrastructure measures (e.g., green roofs, bioretention basins, and bioswales) for flood mitigation purposes to reduce the occurrences of combined sewer overflows and basement flooding. Further investigation into the performance and effectiveness of green infrastructure measures has been conducted by Webber et al. (2020) through the application of a cellular automata-based rapid scenario screening framework to predict the performance of green infrastructure measures for flood management purposes in response to varying intensity rainfall events ranging in intensity from moderate to extreme.

Considering the impact of private-side drainage practices, Jiang et al. (2019) applied a novel statistical approach to investigate the role of rainfall-derived inflow (RDI) from residential foundation drainage systems to evaluate its effect on total rainfall-derived infiltration and inflow (RDII) and occurrences of sewer surcharge. Results from this research found that RDI can be responsible for up to $85 \%$ of total RDII for a case study location in London, Ontario, Canada, highlighting the importance of disconnection of foundation drainage systems from the sewer system in order to reduce occurrences of sewer surcharge and basement flood risk. Considering the effect of RDII, Jiang et al. (2020) investigated a statistical and mathematical approach to develop guidance methodology to evaluate the minimum data requirements for field surveys to evaluate basement flood vulnerability in order to effectively identify appropriate mitigation efforts.

\section{Advances in Private-Side Flood Mitigation Research}

Research into private-side flood mitigation techniques has also been increasing in recent years. In particular, backwater valve research has grown in response to concerns regarding the performance of this technology in various site-specific conditions. Despite growing adoption of this device, concerns have been raised regarding failure of backwater valves during sewer surcharge events that result in raw sewage entering the basement. Irwin et al. (2018) conducted an investigation to compile information on failure of backwater valves and 
determined that valves have been reported to fail as a response to issues concerning the slope and condition of the sewer lateral, wastewater material and flow and pressure conditions. Dusolt et al. (2021) conducted further research into the effect of solids build-up in backwater valves and the reported performance issues and determined that installation and maintenance issues were primary concerns that have adversely impacted backwater valve performance. Dusolt (2019) conducted a comprehensive series of laboratory experiments to evaluate the rate of solids build-up in backwater valves under various configurations and conditions. This research sought to evaluate the effect of lateral slope, composition of wastewater and household density on the rate of solids build-up. This research highlighted the importance of regular homeowner maintenance to remove solids from backwater valves and revealed that increased maintenance intervals are required in certain circumstances.

Infiltration flooding has also gained increased research in recent years. Asphaug et al. (2020) considered moisturerelated damage in basements driven by primarily infiltration mechanisms and examined recommendations from various cold climate countries to assess similarities and differences in national building recommendations. The authors discovered similar recommendations in lot grading and the presence of drainage layers and drainage pipes, while differences in recommendations pertained to the use of exterior damproofing, dimpled membranes and vapor barriers. Kaur et al. (2021) discussed the factors that affect the performance of foundation drainage systems and presented the design of a novel laboratory apparatus to conduct experimental research to quantify infiltration pathways to drainage systems and better understand performance and maintenance issues. Further research is required to evaluate the mechanisms responsible for infiltration flooding into basements and better understand the performance of foundation drainage.

\section{Disaster Risk Reduction Perception and Behavior}

There exists a substantial literature summarizing studies that have attempted to explain factors that affect public, individual, and household adaption of risk reduction measures. These studies have been applied for a variety of hazards, notably flood, including river, coastal, and urban flash flooding (Grothmann and Reusswig, 2006; Terpstra et al., 2009; Terpstra, 2011; Bubeck et al., 2012; Koerth et al., 2013; Dittrich et al., 2016; FoxRogers et al., 2016; Haer et al., 2016; Babcicky and Seebauer, 2017; Richert et al., 2017; Erdlenbruch and Bonte, 2018; Botzen et al., 2019), and also earthquake (Mulilis and Lippa, 1990; Lindell and Perry, 2000; Tanes and Cho, 2013; Joffe et al., 2016), wildland-urban interface fire (Martin et al., 2007; Shafran, 2008; Mozumder et al., 2009; Penman et al., 2016, 2017), disaster preparedness (Glik et al., 2014; Jassempour et al., 2014; Adame and Miller, 2015; Thomas et al., 2018), climate change impacts including sea-level rise (Semenza et al., 2011; Song and Peng, 2017), tornado (Chaney et al., 2013), and other hazards including landslide (Mertens et al., 2018).
Studies have applied a range of theoretical models, including Protection Motivation Theory (PMT) (Poussin et al., 2014; Haer et al., 2016; Bamberg et al., 2017; Erdlenbruch and Bonte, 2018; Mertens et al., 2018; Botzen et al., 2019), vested interest theory (De Dominicis et al., 2014), the Theory of Planned Behavior (Nox and Myles, 2017), the Transtheoretical Model (Martin et al., 2007), and approaches based on the findings of behavioral economics (Linnemayr et al., 2016; Mol et al., 2020), as well as hybrids of these models (Martin et al., 2007). Generally, perception and behavior research seeks to explore and help explain perceptions, behavior and behavioral intentions related to disaster risk reduction planning by individuals, and to offer recommendations on disaster risk reduction initiatives that include motivating individual property owners to undertake household or property-level risk reduction actions.

Behavioral economics approaches have been advanced to motivate behavior with respect to disaster risk reduction ( $\mathrm{Mol}$ et al., 2020). While these approaches have to date rarely been applied in the field of disaster preparedness and response, they have resulted in favorable results in similar decision making contexts (where benefits of investments are uncertain, where behavior change may benefit others more than the individual making the change). Programs based on behavioral economics have been found to be relatively effective when applied to subjects including public health, personal finance (e.g., retirement savings), and voter turnout (Linnemayr et al., 2016). Researchers in behavioral economics have also offered practical guidance on how disaster risk managers can apply findings of behavioral economics to improve programs that aim to improve public understanding of hazards and risk, and motivate behavior. For example, it has been argued that simple changes in messaging concerning return periods could be made to improve the impact of disaster education initiatives (e.g., stop referencing return intervals such as " 1 in 100 year" in flood education materials, and instead focus on the likelihood that a homeowner could be flooded throughout the tenure of their home ownership) (Meyer and Kunreuther, 2017).

Reflecting the experience of basement flood public engagement program managers in Canada, the perception and behavior literature has consistently argued that many at risk households do not invest in cost-effective mitigation measures across a range of hazards (Martin et al., 2007; Botzen et al., 2019). For example, low rates of uptake of interventions to reduce hurricane risk have been identified in the United States (Meyer et al., 2014). Intensive coastal flood risk reduction measures, such as elevating homes following Hurricane Sandy in New York, were influenced by building regulations rather than voluntary action by households (Botzen et al., 2019). Thomas et al. (2018) found that uptake of disaster preparedness kits and family disaster plans was limited following relatively intensive interventions, including intensive education sessions and multiple reinforcement contacts following the initial session. Jassempour et al. (2014) found similarly limited uptake after several interventions to promote adoption of disaster kits. Further, exposed residents may choose to focus primary on low-effort measures for flood protection (Koerth et al., 2013). 


\section{Limitations of Perceptions and Behavior Research}

Hazard perception and behavior studies have been undertaken for many decades, beginning as early as the 1960s in the US with a focus on flood (for example, Burton and Kates, 1964). Despite this considerable history, Mertens et al. (2018) recently described the literature on adoption of household-level disaster risk reduction measures as "scattered and inconclusive." As such, it may be difficult for a household basement flood program manager, typically working in a municipal engineering or utilities department with limited resources and support to implement a homeowner mitigation program, to draw on the perception literature to develop and refine public education and engagement programs for basement flood protection.

Specific challenges with application of the literature for real-world engagement programs include limited reporting on effect size of interventions (i.e., proportion of households that actually apply mitigation actions), and reporting of relatively small effect sizes (Bamberg et al., 2017; Pagliacci et al., 2020). Further, to date, few studies have explored the topic of urban/pluvial flood risk, and specifically household basement flood risk associated with short-duration, high intensity rainfall events (Pagliacci et al., 2020). With some exceptions (e.g., Dittrich et al., 2016; Botzen et al., 2019), many studies have not explored implementation of high-intensity and/or resource intensive voluntary risk reduction actions (e.g., those requiring investment of significant time and resources for households, such as foundation drain disconnections).

Further, interventions that have been promoted in the literature to encourage risk reduction behavior may be considered relatively intensive, and include demonstration sites, property-level evaluations, and dedicated support for risk reduction activities (Martin et al., 2007; Jassempour et al., 2014; Dittrich et al., 2016); however, these interventions have uncertain outcomes. For example, Joffe et al. (2016) found a statistically significant increase in preparedness following workshop interventions focusing on earthquake and urban fire preparation. Rather than the interventions themselves, however, property inspections meant to verify uptake of measures was the most important factor driving uptake of measures. Terpstra et al. (2009) found that intensive workshop activities (including flood protection infrastructure visits, attending lectures, face-to-face communication with local officials) produced underwhelming outcomes with respect to changing risk perceptions. A lack of clear findings that interventions increased risk reduction behavior have been identified elsewhere (Tanes and Cho, 2013; Adame and Miller, 2015).

Hazard information is valuable, and has been linked to greater willingness to participate in risk reduction actions (Mozumder et al., 2009). A relatively consistent finding in the perceptions and behavior literature is that those in low risk areas are less likely to engage in risk reduction activities than those in high risk areas (Botzen et al., 2019). A primary concern with urban/basement flooding is that official flood hazard maps are largely unavailable to the public across Canada.

Reliance on surveys and self-reported adaptations, as is common in the perception and behavior literature, may present a challenge to researchers exploring adoption of household-level measures. Many households may not know what the measures are, as they are often integrated into passive plumbing and drainage systems. For example, in a neighborhood that had been exposed to repeated flood events and relatively intensive public engagement efforts, $32 \%$ of 674 respondents were not able to identify whether they had a sewer backflow protection device in their home (Sandink, 2011).

\section{Engaging Households in Risk Reducing Behavior}

Regardless of the above-noted limitations, a number of consistent findings in the literature may help guide interventions designed to affect household urban flood mitigation behavior. A clear theme in the literature is that common or traditional approaches to engaging the public in disaster preparedness, including provision of information on hazard and risk reduction options to the public, and other measures relying on an information deficit approach, have not had a significant impact of on adoption of physical risk reduction measures (Fox-Rogers et al., 2016; Linnemayr et al., 2016).

It has been argued that response efficacy and self-efficacy may play a role in adoption of mitigation measures (Penman et al., 2017; Botzen et al., 2019). Low levels of self-efficacy, with respect to the measures available to individuals and their ability to implement measures, may limit uptake of actions (Fox-Rogers et al., 2016; Mertens et al., 2018). Communication focusing on how to cope with flooding may increase interest in adoption of mitigation actions (Haer et al., 2016; Erdlenbruch and Bonte, 2018). Applying PMT, Poussin et al. (2014) argued that coping appraisals (variables concerning perceived self-efficacy, responseefficacy, and time and resources needed to implement measures) had a more important influence on mitigation behavior, when compared to threat appraisals (perception of probability and damage associated with flooding).

It has been argued that risk reduction behavior can be supported though increased belief in ones' exposure to risk, the perceived severity of the risk, belief that the risk can be avoided, and perceived efficacy of household measures available to reduce risk (Martin et al., 2007; Dittrich et al., 2016). As stated by Martin et al. (2007: 898), "people must feel they have the knowledge, ability, and resources to deal with the risk at hand and that the actions they take will effectively reduce the risk, before they are ready to move into the action stage of risk reduction."

In the development and implementation of public engagement programs, individuals may be differentiated based on the stage of their decision making process, including distinguishing those who have not yet decided to change behavior, to those who have decided that they will make a change to their behavior, to those who have already engaged in risk reduction actions. Individuals at different stages in the decision making process may require different motivations to progress in the decision making process (Martin et al., 2007). Further, the influence of neighbors (e.g., those conducting visible vegetation management for WUI fire) have been noted (Shafran, 2008). Haer et al. (2016) also identified a role for propagating information through social networks in the context of flood risk, 
though an exploration of the use of norm-nudges for flood risk reduction behavior by Mol et al. (2020) did not provide evidence that they could be used to increase flood preparedness. Further, Babcicky and Seebauer (2017) found that social capital increased perceived self-efficacy for flood preparedness, but also reduced flood risk perceptions due to expectations of social support during disasters.

\section{DISCUSSION}

\section{Recommendations for Reducing Urban Flood Risk}

Considerable information and knowledge exist on damages and protection for other forms of flooding (e.g., coastal and riverine flooding). Owing partly to urban pluvial flooding's exclusion from traditional river and coastal flood risk management options in Canada, relatively less is known about pluvial flooding in urban environments as it pertains to the mechanisms responsible for causing basement flooding and the approaches to mitigate damages and insured losses. Despite the numerous challenges and complexities with respect to basement flooding and the responsible mechanisms, there are encouraging opportunities to better understand this phenomenon and appoint more appropriate and effective private-side flood mitigation measures to lead to reduced flood risk. As discussed in this paper, these include the advancements made in research as well as the development of a better understanding of the inter-relationship between the influencing factors affecting basement flooding and an appreciation of the inherent challenges of private-side flood mitigation approaches.

As illustrated in Figure 5, continued improvements in urban flood risk reduction rely on: (1) understand the causes and driving factors responsible for basement flooding; (2) research performance, suitability and optimization of privateside flood mitigation measures; (3) understand and address voluntary adoption of household flood risk reduction, including maintenance of measures; (4) develop non-voluntary methods to incorporate risk reduction in new and existing buildings; and (5) promote iterative processes for reducing flood risk.

\section{Understand the Causes and Driving Factors Responsible for Basement Flooding}

Complex processes and mechanisms affecting a neighborhood or an individual residential home make it difficult to assess the vulnerability to flooding at the site-scale. The interrelated factors, including socio-political, environmental and infrastructure factors, can result in flood vulnerability that differs for homes in relative close proximity. Numerous independent factors influence the risk of flooding from sewer backup, infiltration and overland mechanisms. For instance, sewer backup flooding can be affected by sewer network characteristics, the condition of the sewer lateral, and local drainage characteristics. Infiltration flooding, on the other hand, can be highly influenced by groundwater conditions, soil properties and infiltration characteristics, and lot drainage characteristics. Overland flooding can be affected by characteristics including the proximity to rivers, large-scale (i.e., catchment-scale) stormwater management features and local topography (i.e., elevation). Further research is required to bring together all of these factors to better identify site-specific flood vulnerability and understand the complexity or urban flooding.

\section{Research Performance, Suitability and Optimization of Private-Side Flood Mitigation Measures}

Research efforts to better understand the private-side flood mitigation measures (such as backwater valves and foundation drainage systems) is presently limited; further efforts are needed to characterize the efficacy and performance of these measures and determine their suitability for specific conditions. This includes understanding the effect of variability in lot-specific conditions as well as the relation between private-side flood mitigation measures and large-scale drainage and watershed conditions. This research is also required to understand the longterm performance of private-side flood mitigation, including the effect of future environmental change (e.g., changes in climate, changes in land-use, etc.). This knowledge will also lead to the development of insight into required maintenance for these measures and will aid in design of strategies to communicate this to homeowners.

\section{Understand and Address Voluntary Adoption of Household Flood Risk Reduction, Including Maintenance of Measures}

The successful adoption of suitable private-side flood mitigation measures is complicated by challenges related to public awareness and engagement and jurisdictional issues, which can cause uncertainty with respect to the available technologies and approaches and with whom the responsibility lies. Movement away from information-deficit models, and greater emphasis on factors that have been found to better drive public engagement flood risk reduction (e.g., self-efficacy) is warranted.

Recently, national guidance on household level interventions for flood risk have been published (Canadian Standards Association, 2018). With the exception of Sandink (2007, 2011), no studies have been identified that examine public and homeowner understanding and reaction to public engagement programs focused specifically on urban flooding in Canada. There remains, therefore, a research gap in understanding public motivations to engage in urban/basement flood mitigation options.

Additional work is required to identify, develop, and evaluate models of effective public engagement in the context of urban flood in Canada. Studies have evaluated resourceintensive interventions (e.g., multiple workshops, meetings, interventions), with mixed results. In some circumstances, studies have indicated an uptake in mitigation measureshowever, effect size is not always large, and it is not clear that consistent advice is available to achieve uptake levels of $50 \%$ or more that may be required to adequately control basement flood risk and I/I (see Chambers, 2014).

Where appropriate flood mitigation measures are adopted, they will have to be maintained to ensure efficacy. This process requires homeowner understanding of mitigation technology present in the home, and appropriate support for maintenance. Attention must also be given to ensure that the knowledge 


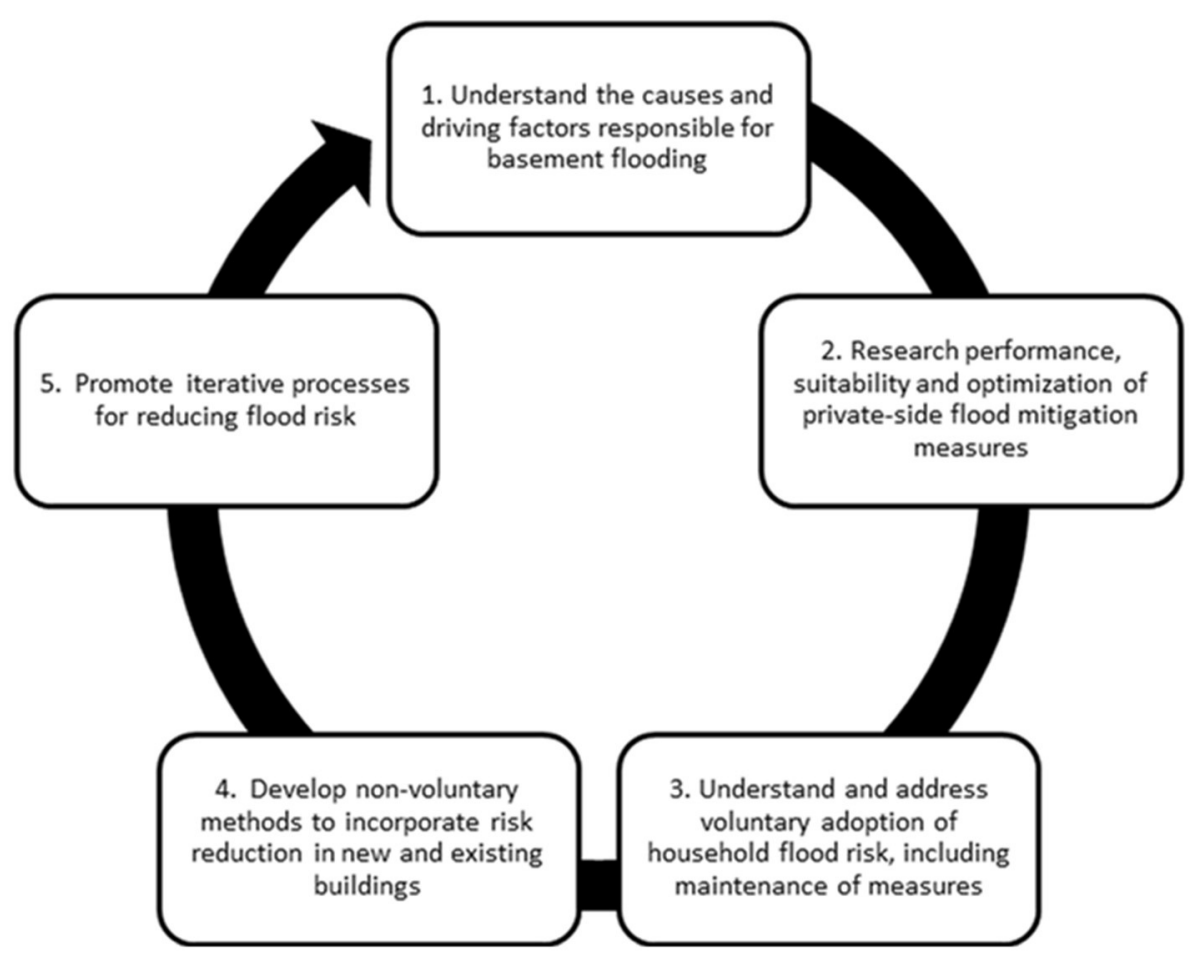

FIGURE 5 | Recommended steps for reducing risk of urban flooding events through private-side flood mitigation measures.

of private-side flood mitigation technology is transferred when homes change ownership. It is also important for homeowners to understand how the private-side flood mitigation measures present in the home reduce exposure of the home to basement flooding and reduce the risk of water damage from flooding events.

\section{Develop Non-voluntary Methods to Incorporate Risk Reduction in New and Existing Buildings}

Given the uncertain effectiveness and potential complexity of public engagement programs, effective urban flood risk reduction work should incorporate advances in new building regulations (e.g., construction codes) and retrofit requirements (e.g., time-ofsale, time of renovation requirements), where private-side flood mitigation measures can be implemented during key windows of opportunity to ensure their implementation and integration into an adequate proportion of homes. This work should be supported by appropriate evaluations of costs and benefits of household-level flood risk reduction options.

For example, the Multi-Hazard Mitigation Council (2019) identified favorable benefit-cost ratios (BCRs) for a variety of disaster mitigation measures that exceeded US-relevant construction code advice. This work focused on wet and dry flood proofing provisions that support flood insurance implementation in the US. Site/property-scale wildland fire risk reduction measures have been studied using a similar approach in Canada, and have also found extremely favorable BCRs (Porter et al., 2021). To date, however, a comprehensive benefit cost analysis that includes understanding of societal benefits for reducing flood risk, has not been conducted for basement flood protection measures in Canada.

Assessments of the societal benefits and costs of urban flood risk reduction should incorporate issues surrounding vulnerable segments of society, including those who occupy basement or below-grade dwellings. Municipalities lack data on basement apartment occupancies, and in many cases residents may occupy illegal residences. It is unlikely, therefore, that the experience of these residents is incorporated into flood risk reduction programs. Research conducted elsewhere concerning resiliency of residents and recovery capacity may serve as a model for further work in this area (Chen and Leandro, 2019).

\section{Promote Iterative Processes for Reducing Flood Risk}

Lastly, recommended steps for reducing urban flood risk through private-side measures illustrated in Figure 5 are a continuous cycle, in which the implementation and experience (e.g., success, failure, challenges, etc.) of privateside flood mitigation measures will assist in informing greater insights into flood vulnerability, direct further research into technology and approaches to reduce the risk of basement flooding and assist in successful adoption and implementation of voluntary and non-voluntary flood mitigation measures. Altogether, this will lead to improved private-side flood protection options available to homeowners to provide greater protection against water damage from urban flood events. 


\section{CONCLUDING REMARKS}

This review paper presented and discussed the socio-political, environmental, and infrastructure factors that affect the risk of basement flooding and the flood mitigation measures that can be implemented to reduce risk of water damage from overland, infiltration and sewer backup flooding events. Numerous challenges exist that have hindered more widespread adoption of household and property measures to reduce the risk of urban flood damage. These challenges highlight the need for improved engagement of homeowners to provide greater awareness of flood vulnerability and mitigation, development of a greater knowledge to identify the specific causes (or mechanisms) responsible for basement flooding, and the need to reduce uncertainty in the efficacy of private-side mitigation measures.

Local jurisdictions respond immediately to damaging urban flood events, and must work to mitigate risk with the available tools, including private-side flood mitigation options and devices. Decisions must be made in the post disaster period, regardless of the dearth of research concerning design and long-term efficacy of flood protection devices. Improved understanding of performance of private-side interventions is needed, as is practical guidance on effective engagement of households in disaster risk reduction-including methods that result in widespread uptake of relevant risk reduction options. Tools and methods for urban flood risk management must be developed to reflect the context of limited time and resources for comprehensive urban flood management by locallevel practitioners.

Further research is required to better understand the interrelationships between the various factors influencing flood vulnerability and to understand the performance and suitability

\section{REFERENCES}

Abboud, J. M., Ryan, M. C., and Osborn, G. D. (2018). Groundwater flooding in a river-connected alluvial aquifer. J. Flood Risk Manage. 11:e12334. doi: $10.1111 /$ jfr3.12334

Adame, B. J., and Miller, C. H. (2015). Vested interest, disaster preparedness, and strategic campaign message design. Health Commun. 30, 271-281. doi: 10.1080/10410236.2013.842527

Ahn, K. H., and Merwade, V. (2016). Role of watershed geomorphic characteristics on flooding in Indiana, United States. J. Hydrol. Eng. 21:05015021. doi: 10.1061/(ASCE)HE.1943-5584.0001289

Asphaug, S. K., Kvande, T., Time, B., Peuhkuri, R. H., Kalamees, T., Johansson, P., et al. (2020). Moisture control strategies of habitable basements in cold climates. Build. Environ. 169:106572. doi: 10.1016/j.buildenv.2019.106572

Babcicky, P., and Seebauer, S. (2017). The two faces of social capital in private flood mitigation: opposing effects on risk perception, self-efficacy and coping capacity. J. Risk Res. 20, 1017-1037. doi: 10.1080/13669877.2016.1147489

Bamberg, S., Masson, T., Brewitt, K., and Nemetschek, N. (2017). Threat, coping and flood prevention - a meta-analysis. J. Environ. Psychol. 54, 116-126. doi: 10.1016/j.jenvp.2017.08.001

Bergman, W. A., and Kapadia, D. H. (1988). Tunnel and reservoir plan solution to Chicago's combined sewer overflow, basement flooding, and pollution. Can. J. Civil Eng. 15, 389-396. doi: 10.1139/188-054

Botzen, W. J. W., Kunreuther, H., Czajkowski, J., and de Moel, H. (2019). Adoption of individual flood damage mitigation measures in New York city: an extension of protection motivation theory. Risk Anal. 39, 2143-2159. doi: $10.1111 /$ risa. 13318 of flood mitigation measures in order to identify and prioritize private-side flood mitigation strategies based on site-specific conditions and flood vulnerability factors. Altogether, this will help to narrow the gap between research and practice and provide homeowners with greater tools to reduce their exposure to damaging urban flooding events.

\section{DATA AVAILABILITY STATEMENT}

The original contributions presented in the study are included in the article/supplementary material, further inquiries can be directed to the corresponding author.

\section{AUTHOR CONTRIBUTIONS}

This manuscript was a collaborative effort by DS and AB. Both authors contributed to the intellectual content of the manuscript and have approved this manuscript to be submitted for consideration in this journal.

\section{FUNDING}

This research was funded by the Institute for Catastrophic Loss Reduction (ICLR) and the Natural Sciences and Engineering Research Council of Canada (NSERC) through the Collaborative Research and Development grant program (Grant Numbers: $\# 053309$ and \#401262).

\section{ACKNOWLEDGMENTS}

The authors acknowledge Julien Gordon's assistance with the review of perception and behavior literature.

Brody, S., Blessing, R., Sebastian, A., and Bedient, P. (2014). Examining the impact of land use/land cover characteristics on flood losses. J. Environ. Planning Manage. 57, 1252-1265. doi: 10.1080/09640568.2013.802228

Brown, K., and Hill, C. (2003). "Development of a basement flooding remediation strategy," in Practical Modeling of Urban Water Systems, Monograph 11, ed W. James (Guelph, ON: CHI Publications), 107.

Bubeck, P., Botzen, W. J. W., and Aerts, J. C. J. H. (2012). A review of risk perceptions and other factors that influence flood mitigation behavior. Risk Anal. 32, 1481-1495. doi: 10.1111/j.1539-6924.2011.01783.x

Burton, I., and Kates, R. (1964). The perception of natural hazards in resource management. Nat. Resour. J. 3, 412-441.

Canadian Standards Association (2018). CSA Z800-18 - Basement Flood Protection and Risk Reduction Guideline. Canadian Standards Association. Available online at: https://www.csagroup.org/store/product/Z800-18/

Carr, R. W., Esposito, C., and Walesh, S. G. (2001). Street-surface storage for control of combined sewer surcharge. J. Water Resour. Plann. Manage. 127, 162-167. doi: 10.1061/(ASCE)0733-9496(2001)127:3(162)

Catastrophe Indices and Quantification Inc. (2020). CatIQ Bulletins. CatIQ. Available online at: https://public.catiq.com/

Chambers, K. (2014). Private side weeping tile disconnections from the sanitary sewer to prevent basement flooding in London Ontario. Proc. Water Environ. Feder. 2014, 6011-6027. doi: 10.2175/1938647148159 43232

Chaney, P. L., Weaver, G. S., and Youngblood, S. A. (2013). Household preparedness for Tornado hazards: the 2011 disaster in DeKalb County, Alabama. Weather Climate Soc. 5, 345-358. doi: 10.1175/WCAS-D-1200046.1 
Chen, K. F., and Leandro, J. (2019). A conceptual time-varying flood resilience index for urban areas: Munich city. Water 11:830. doi: 10.3390/w11040830

City of Chicago (2021). Downspout Disconnection. Available online at: https:// chicago.gov/city/en/depts/water/supp_info/conservation/downspout_ disconnection.html (accessed June 4, 2021).

City of Ottawa (2021). Sewer Backups and Basement Flooding. Available online at: https://ottawa.ca/en/living-ottawa/water/wastewater-and-sewers/ sewer-backups-and-basement-flooding (accessed March 10, 2021).

City of Toronto (2018). As-of-Right Zoning for Secondary Suites. PG31.12 Report for Action. Toronto, ON: City of Toronto.

City of Toronto (2019). City of Toronto's First Resilience Strategy. City of Toronto. Available online at: https://www.toronto.ca/services-payments/ water-environment/environmentally-friendly-city-initiatives/resilientto/

City of Vancouver (2020). Fix Leaks, Floods, and Sewage Problems. Available online at: https://vancouver.ca/home-property-development/problems-withleaks-floods-and-sewage.aspx (accessed January 12, 2021).

City of Windsor (2017). Special Meeting of City Council. Agenda, January 23, 2017. Windsor, ON: City of Windsor.

De Dominicis, S., Crano, W. D., and Cancellieri, U. G. (2014). Vested interest and environmental risk communication: improving willingness to cope with impending disasters. J. Appl. Soc. Psychol. 44, 364-374. doi: 10.1111/jasp.12229

Dittrich, R., Wreford, A., and Butler, A. (2016). The impact of flood action groups on the uptake of flood management measures. Clim. Change 138, 471-489. doi: 10.1007/s10584-016-1752-8

Dusolt, S. (2019). Evaluating the performance of backwater valves as a lot-level approach to reduce basement flooding in Canadian homes (Master's thesis), University of Guelph, Guelph, ON, Canada.

Dusolt, S., Binns, A. D., McBean, E., Gharabaghi, B., and Sandink, D. (2021). Characterization of backwater valves in sanitary sewer laterals and associated failures in a Canadian context. Can. J. Civil Eng. 48, 829-837. doi: 10.1139/cjce-2020-0026

Dutt, L., and Hemphill, B. (2004). "Creating a toolbox for optimizing basement flooding relief alternatives," in Critical Transitions in Water and Environmental Resources Management: Proc. 2004 World Water and Environmental Resources Congress (Reston, VA: American Society of Civil Engineers), 1-9. doi: 10.1061/40737(2004)379

East Bay Municipal Urban District (n.d.). East Bay Regional Private Sewer Lateral Program. Available online at: https://www.eastbaypsl.com/eastbaypsl/ (accessed June 4, 2021).

Environment and Climate Change Canada (2017). Engineering Climate Datasets. Ottawa, ON: Environment and Climate Change Canada.

Erdlenbruch, K., and Bonte, B. (2018). Simulating the dynamics of individual adaptation to floods. Environ. Sci. Policy 84, 134-148. doi: 10.1016/j.envsci.2018.03.005

Fox-Rogers, L., Devitt, C., O'Neill, E., Brereton, F., and Clinch, J. P. (2016). Is there really 'nothing you can do'? Pathways to enhanced flood-risk preparedness. J. Hydrol. 543, 330-343. doi: 10.1016/j.jhydrol.2016.10.009

Friedland, J., Cheng, H., and Peleshok, A. (2014). Water Damage Risk and Canadian Property Insurance Pricing. Toronto, ON: Canadian Institute of Actuaries.

Glik, D. C., Eisenman, D. P., Zhou, Q., Tseng, C., and Asch, S. M. (2014). Using the precaution adoption process model to describe a disaster preparedness intervention among low-income latinos. Health Educ. Res. 29, 272-283. doi: 10.1093/her/cyt109

Government of Manitoba (2019). Flood Fact Sheet. Available online at: https:// www.gov.mb.ca/asset_library/en/spring_outlook/floodwater_and_your_ health.pdf (accessed January 12, 2021).

Grothmann, T., and Reusswig, F. (2006). People at risk of flooding: why some residents take precautionary action while others do not. Nat. Hazards 38, 101-120. doi: 10.1007/s11069-005-8604-6

Haer, T., Botzen, W. J. W., and Aerts, J. C. J. H. (2016). The effectiveness of flood risk communication strategies and the influence of social networks-insights from an agent-based model. Environ. Sci. PolicyJ. Environ. Manage. 60, 44-52. doi: 10.1016/j.envsci.2016.03.006

Haghighatafshar, S., Nordlöf, B., Roldin, M., Gustafsson, L. G., la Cour Jansen, J., and Jönsson, K. (2018). Efficiency of blue-green stormwater retrofits for flood mitigation-conclusions drawn from a case study in Malmö, Sweden. J. Environ. Manage. 207, 60-69. doi: 10.1016/j.jenvman.2017.11.018
Horizon Engineering (2020). Builder Guide to Site \& Foundation Drainage Best Practices for Part 9 Buildings in British Columbia. Prepared for BC Housing. Vancouver, BC: Horizon Engineering.

Institute for Catastrophic Loss Reduction (2017). Municipal Basement Flood Subsidy Programs. Toronto, ON: Institute for Catastrophic Loss Reduction.

Insurance Bureau of Canada (2020). Facts of the Property and Casualty Insurance Industry in Canada. Toronto, ON: Insurance Bureau of Canada.

Insurance Canada (2018). Nearly Half of Tenants Have No Renter's Insurance. Available online at: https://www.insurance-canada.ca/2018/04/11/kanetixtenants-renters/ (accessed January 12, 2021).

Irwin, S., Howlett, C., Binns, A. D., and Sandink, D. (2018). Mitigation of basement flooding due to sewer backup: overview and experimental investigation of backwater valve performance. Nat. Hazards Rev. 19:04018020. doi: 10.1061/(ASCE)NH.1527-6996.0000298

Jassempour, K., Shirazi, K. K., Fararooei, M., Shams, M., and Shirazi, A. R. (2014). The impact of educational intervention for providing disaster survival kit: applying precaution adoption process model. Int. J. Disaster Risk Reduc. 10, 374-380. doi: 10.1016/j.ijdrr.2014.10.012

Jiang, A. Z., McBean, E. A., Binns, A., and Gharabaghi, B. (2019). Quantifying rainfall-derived inflow from private foundation drains in sanitary sewers: case study in London, Ontario, Canada. J. Hydrol. Eng. 24:05019023. doi: 10.1061/(ASCE)HE.1943-5584.0001814

Jiang, A. Z., McBean, E. A., Binns, A. D., and Gharabaghi, B. (2020). Guidance on field survey programme design for basement flooding assessment. Hydrol. Sci. J. 1-10. doi: 10.1080/02626667.2020.1782412. [Epub ahead of print].

Joffe, H., Perez-Fuentes, G., Potts, H. W., and Rossetto, T. (2016). How to increase earthquake and home fire preparedness: the fix-it intervention. Nat. Hazards 84, 1943-1965. doi: 10.1007/s11069-016-2528-1

Kaur, B., Binns, A. D., Sandink, D., Gharabaghi, B., and McBean, E. A. (2021). "Reducing the risk of basement flooding through building- and lot-scale flood mitigation approaches: performance of foundation drainage systems," in Proceedings of CSCE (Canadian Society for Civil Engineering) 2021 Annual Conference (Hydrotechnical Specialty Conference), 26-29 May, held virtually, Canada (Pointe-Claire, QC).

Koerth, J., Jones, N., Vafeidis, A. T., Dimitrakopoulos, P. G., Melliou, A., Chatzidimitriou, E., et al. (2013). Household adaptation and intention to adapt to coastal flooding in the Axios-Loudias-Aliakmonas National Park, Greece. Ocean Coast. Manag. 82, 43-50. doi: 10.1016/j.ocecoaman.2013.05.008

Kreibich, H., and Thieken, A. H. (2008). Assessment of damage caused by high groundwater inundation. Water Resour. Res. 44. doi: 10.1029/2007WR006621

Kyriazis, J., Zizzo, L., and Sandink, D. (2017). Assessing Local Mandatory Measures to Reduce Flood Risk and Inflow \& Infiltration in Existing Homes. Institute for Catastrophic Loss Reduction. Available online at: https://www.iclr.org/ wp-content/uploads/PDFS/assessing-local-mandatory-measures-to-reduceflood-fisk-and-inflow-infiltration-in-existing-homes.pdf

Ladson, A. R., and Tilleard, J. (2013). Reducing flood risk associated with basement drainage. Austral. J. Water Resourc. 17, 101-104. doi: 10.7158/W12-029.2013.17.1

Leandro, J., Chen, A. S., Djordjević, S., and Savić, D. A. (2009). Comparison of $1 \mathrm{D} / 1 \mathrm{D}$ and $1 \mathrm{D} / 2 \mathrm{D}$ coupled (sewer/surface) hydraulic models for urban flood simulation. J. Hydraulic Eng. 135, 495-504. doi: 10.1061/(ASCE)HY.1943-7900.0000037

Leandro, J., Chen, K. F., Wood, R. R., and Ludwig, R. (2020). A scalable floodresilience-index for measuring climate change adaptation: Munich city. Water Res. 173:115502. doi: 10.1016/j.watres.2020.115502

Lindell, M. K., and Perry, R. W. (2000). Household adjustment to earthquake hazard: a review of research. Environ. Behav. 32, 461-501. doi: $10.1177 / 00139160021972621$

Linnemayr, S., O’Hanlon, C., Uscher-Pines, L., Van Abel, K., and Nelson, C. (2016). Using insights from behavioral economics to strengthen disaster preparedness and response. Disaster Med. Public Health Prep. 10, 768-774. doi: $10.1017 /$ dmp.2016.29

Mainline Backwater Valves, Inc. (2013). Mainline Fullport Backwater Valve. Available online at: http://backwatervalve.com/products/fullport-backwatervalve.html (accessed March 10, 2021).

Martin, I. M., Bender, H., and Raish, C. (2007). What motivates individuals to protect themselves from risks: the case of wildland fires. Risk Anal. Int. J. 27, 887-900. doi: 10.1111/j.1539-6924.2007.00930.x 
Mertens, K., Jacobs, L., Maes, J., Poesen, J., Kervyn, M., and Vranken, L. (2018). Disaster risk reduction among households exposed to landslide hazard: a crucial role for self-efficacy? Land Use Policy 75, 77-91. doi: 10.1016/j.landusepol.2018.01.028

Metro Vancouver (2008). Private Sewer Lateral Programs: A Study of Approaches and Legal Authority for Metro Vancouver Municipalities. Burnaby, BC: Metro Vancouver.

Metro Vancouver Liquid Waste Services Department (2016). Private Lateral Foundation Drains and Semi-Combined Sewers as an Inflow and Infiltration Source. Burnaby, BC: Metro Vancouver.

Meyer, R., and Kunreuther, H. (2017). The Ostrich Paradox: Why We Underprepare for Disasters. Philadelphia, PA: Wharton School Press.

Meyer, R. J., Baker, J., Broad, K., Czajkowski, J., and Orlove, B. (2014). The dynamics of hurricane risk perception: realtime evidence from the 2012 Atlantic hurricane season. Bull. Am. Meteorol. Soc. 95, 1389-1404. doi: 10.1175/BAMS-D-12-00218.1

Miller, J. D., and Hutchins, M. (2017). The impacts of urbanisation and climate change on urban flooding and urban water quality: a review of the evidence concerning the United Kingdom. J. Hydrol. Regional Stud. 12, 345-362. doi: 10.1016/j.ejrh.2017.06.006

Mobini, S., Becker, P., Larsson, R., and Berndtsson, R. (2020). Systemic inequity in urban flood exposure and damage compensation. Water 12:3152. doi: $10.3390 / \mathrm{w} 12113152$

Mol, J. M., Botzen, W. W., Blasch, J. E., Kranzler, E. C., and Kunreuther, H. C. (2020). All by myself? Testing descriptive social norm-nudges to increase flood preparedness among homeowners. Behav. Public Policy 1-33. doi: $10.2139 /$ ssrn.3616189

Mozumder, P., Helton, R., and Berrens, R. P. (2009). Provision of a wildfire risk map: informing residents in the wildland urban interface. Risk Anal. Int. J. 29,1588-1600. doi: 10.1111/j.1539-6924.2009.01289.x

Mulilis, J. P., and Lippa, R. (1990). Behavioral change in earthquake preparedness due to negative threat appeals: a test of protection motivation theory. J. Appl. Soc. Psychol. 20, 619-638. doi: 10.1111/j.1559-1816.1990.tb00429.x

Multi-Hazard Mitigation Council (2019). Natural Hazard Mitigation Saves: 2019 Report. eds. K. Principal Investigator Porter, N. Co-Principal Investigators Dash, C. Huyck, J. Santos, C. Scawthorn, M. Eguchi, R. Eguchi, S. Ghosh, M. Isteita, K. Mickey, T. Rashed, A. Reeder, P. Schneider, and J. Yuan (Washington, DC: National Institute of Building Sciences). Available online at: www.nibs.org

Nelson, D., Cantrell, C., and Gross, J. (2005). "Columbus private source infiltration and inflow identification pilot program," in Proceedings of the Water Environment Federation, WEFTEC 2005, Session 81 Through Session, Vol. 90 (Alexandria, VA), 6845-6859. doi: 10.2175/193864705783858927

Nie, L., Lindholm, O., Lindholm, G., and Syversen, E. (2009). Impacts of climate change on urban drainage systems-a case study in Fredrikstad, Norway. Urban Water J. 6, 323-332. doi: 10.1080/15730620802600924

Nox, R., and Myles, C. C. (2017). Wildfire mitigation behavior on single family residential properties near Balcones Canyonlands Preserve wildlands in Austin, Texas. Appl. Geogr. 87, 222-233. doi: 10.1016/j.apgeog.2017. 08.010

Oulahen, G., and Doberstein, B. (2012). Citizen participation in post-disaster flood hazard mitigation planning in Peterborough, Ontario, Canada. Risk Hazards Crisis Public Policy 3, 1-26. doi: 10.1515/1944-4079.1098

Owusu, S., Wright, G., and Arthur, S. (2015). Public attitudes towards flooding and property-level flood protection measures. Nat. Hazards 77, 1963-1978. doi: 10.1007/s11069-015-1686-x

Pagliacci, F., Defrancesco, E., Bettella, F., and D'Agostino, V. (2020). Mitigation of urban pluvial flooding: what drives residents' willingness to implement green or grey stormwater infrastructures on their property? Water 12:3069. doi: 10.3390/w12113069

Pawlowski, C., Rhea, L., Shuster, D., and Braden, G. (2014). Some factors affecting inflow and infiltration from residential sources in a core urban area: case study in Columbus, Ohio, neighborhood. J. Hydraulic Eng. 140, 105-114. doi: 10.1061/(ASCE)HY.1943-7900.0000799

Pearlman, S. (2017). Minimizing Municipal Costs for Inflow and Infiltration Remediation: A Handbook for Municipal Officials. Canton, OH: Neponset River Watershed Association.

Peiying, T., Yongchao, Z., Yiping, Z., Zhu, D., and Tuqiao, Z. (2019). Assessment and pathway determination for rainfall-derived inflow and infiltration in sanitary systems: a case study. Urban Water J. 16, 600-607. doi: 10.1080/1573062X.2019.1700289

Penman, T. D., Eriksen, C., Horsey, B., Green, A., Lemcke, D., Cooper, P., et al. (2017). Retrofitting for wildfire resilience: what is the cost? Int. J. Disaster Risk Reduc. 21, 1-10. doi: 10.1016/j.ijdrr.2016.10.020

Penman, T. D., Eriksen, C. E., Horsey, B., and Bradstock, R. A. (2016). How much does it cost residents to prepare their property for wildfire? Int. J. Disaster Risk Reduc. 16, 88-98. doi: 10.1016/j.ijdrr.2016.01.012

Peterborough Public Health (n.d.). Protect Yourself During Flood Conditions. Flooding. Available online at: https://www.peterboroughpublichealth.ca/yourhealth/home-health-and-safety/flooding/ (accessed January 13, 2021).

Porter, K. A., Scawthorn, C. R., and Sandink, D. (2021). An Impact Analysis for the National Guide for Wildland-Urban Interface Fires. Prepared for the National Research Council of Canada. Institute for Catastrophic Loss Reduction, Toronto, ON, 136.

Poussin, J. K., Botzen, W. W., and Aerts, J. C. (2014). Factors of influence on flood damage mitigation behaviour by households. Environ. Sci. Policy 40, 69-77. doi: 10.1016/j.envsci.2014.01.013

Province of Ontario (2011). Bill 140, Strong Communities through Affordable Housing Act. Toronto, ON: Legislative Assembly of Ontario.

Province of Ontario (2016). Promoting Affordable Housing Act. 2016, S.O. 2016, c. 25 - Bill 7. Toronto, ON: Legislative Assembly of Ontario.

Richert, C., Erdlenbruch, K., and Figuières, C. (2017). The determinants of households' flood mitigation decisions in France-on the possibility of feedback effects from past investments. Ecol. Econ. 131, 342-352. doi: 10.1016/j.ecolecon.2016.09.014

Robinson, B., Sandink, D., and Lapp, D. (2019). Reducing the Risk of Inflow and Infiltration (I/I) in New Sewer Construction. Institute for Catastrophic Loss Reduction \& Standards Council of Canada. Available online at: https://www.scc.ca/sites/default/files/files/SCC_RPT_Norton-ICLREC-SCC-II-in-New-Sewer-Construction-2019-11-20_ENG.pdf

Robinson, B., and Sandink, D. (2021). Developing an Efficient and Cost-Effective Inflow and Infiltration (I/I) Reduction Program. Toronto, ON; Ottawa, ON: Institute for Catastrophic Loss Reduction \& Standards Council of Canada.

Sampson, N. R., Price, C. E., Kassem, J., Doan, J., and Hussein, J. (2019). "We're just sitting ducks": recurrent household flooding as an underreported environmental health threat in Detroit's changing climate. Int. J. Environ. Res. Public Health 16:6. doi: 10.3390/ijerph1601 0006

Sandink, D. (2007). Sewer Backup: Homeowner Perception and Mitigative Behaviour in Edmonton and Toronto. Toronto, ON: Institute for Catastrophic Loss Reduction.

Sandink, D. (2009). Handbook for Reducing Basement Flooding. Institute for Catastrophic Loss Reduction. Available online at: https://www.iclr.org/wpcontent/uploads/PDFS/handbook-for-reducing-basement-flooding.pdf

Sandink, D. (2011). Involving Homeowners in Urban Flood Risk Reduction: A Case Study of the Sherwood Forest Neighbourhood, London, Ontario. Institute for Catastrophic Loss Reduction, ICLR research paper series - number 51. Toronto, ON, 104

Sandink, D. (2013). Urban Flooding in Canada: Lot-Side Risk Reduction Through Voluntary Retrofit Programs, Code Interpretation and By-Laws. Institute for Catastrophic Loss Reduction, ICLR research paper series - number 52. Toronto, ON, 94.

Sandink, D. (2016). Urban flooding and ground-related homes in Canada: an overview. J. Flood Risk Manage. 9, 208-223. doi: 10.1111/jfr3.12168

Sandink, D. (2017). Protect Your Home from Sewer Backup: Procedures for Proper Installation of Backwater Valves. Institute for Catastrophic Loss Reduction. Available online at: http://www.backwatervalveinstallation.com/

Sandink, D., Dale, N., Robinson, B., and Okrutney, P. (2020). Practical Guidance for Private-Side Drainage Systems to Reduce Basement Flood Risk: Addressing Critical Information Gaps. Ottawa, ON: Submitted to the National Research Council of Canada.

Schmitt, T. G., Thomas, M., and Ettrich, N. (2004). Analysis and modeling of flooding in urban drainage systems. J. Hydrol. 299, 300-311. doi: 10.1016/S0022-1694(04)00374-9

Semenza, J. C., Ploubidis, G. B., and George, L. A. (2011). Climate change and climate variability: personal motivation for adaptation and mitigation. Environ. Health 10, 1-12. doi: 10.1186/1476-069X-10-46 
Seyoum, S. D., Vojinovic, Z., Price, R. K., and Weesakul, S. (2012). Coupled 1D and noninertia 2D flood inundation model for simulation of urban flooding. J. Hydraulic Eng. 138, 23-34. doi: 10.1061/(ASCE)HY.1943-7900.0000485

Shafran, A. P. (2008). Risk externalities and the problem of wildfire risk. J. Urban Econ. 64, 488-495. doi: 10.1016/j.jue.2008.05.001

Sheng, J., and Wilson, J. P. (2009). Watershed urbanization and changing flood behavior across the Los Angeles metropolitan region. Nat. Hazards 48, 41-57. doi: 10.1007/s11069-008-9241-7

Skougaard Kaspersen, P., Høegh Ravn, N., Arnbjerg-Nielsen, K., Madsen, H., and Drews, M. (2017). Comparison of the impacts of urban development and climate change on exposing European cities to pluvial flooding. Hydrol. Earth Syst. Sci. 21, 4131-4147. doi: 10.5194/hess-21-4131-2017

Song, J., and Peng, B. (2017). Should we leave? Attitudes towards relocation in response to sea level rise. Water 9:941. doi: 10.3390/w9120941

Soren, J. (1976). Basement Flooding and Foundation Damage From Water-Table Rise in the East New York Section of Brooklyn, Long Island, New York (No. 76-95). Reston, VA: US Geological Survey.

Sörensen, J., and Emilsson, T. (2019). Evaluating flood risk reduction by urban blue-green infrastructure using insurance data. J. Water Resour. Planning Manage. 145:04018099. doi: 10.1061/(ASCE)WR.1943-5452.0001037

Sörensen, J., and Mobini, S. (2017). Pluvial, urban flood mechanisms and characteristics-assessment based on insurance claims. J. Hydrol. 555, 51-67. doi: 10.1016/j.jhydrol.2017.09.039

Steis Thorsby, J., Miller, C. J., and Treemore-Spears, L. (2020). The role of green stormwater infrastructure in flood mitigation (Detroit, MI USA)-case study. Urban Water J. 17, 838-846. doi: 10.1080/1573062X.2020.1823429

Swinton, M. C., and Kesik, T. J. (2008). Site Grading and Drainage to Achieve HighPerformance Basements. Ottawa, ON: Institute for Research in Construction, National Research Council Canada.

Tanes, Z., and Cho, H. (2013). Goal setting outcomes: examining the role of goal interaction in influencing the experience and learning outcomes of video game play for earthquake preparedness. Comput. Human Behav. 29, 858-869. doi: 10.1016/j.chb.2012.11.003

TenBroek, M. J., Perala, P., Hupy, C., Rolfe, C., and Sherman, B. J. (2002). Use of footing drain disconnection to correct basement backups in Ann Arbor, Michigan. Proc. Water Environ. Feder. 2002, 142-162. doi: $10.2175 / 193864702785300692$

Terpstra, T. (2011). Emotions, trust, and perceived risk: affective and cognitive routes to flood preparedness behavior. Risk Anal. Int. J. 31, 1658-1675. doi: 10.1111/j.1539-6924.2011.01616.x

Terpstra, T., Lindell, M. K., and Gutteling, J. M. (2009). Does communicating (flood) risk affect (flood) risk perceptions? Results of a quasi-experimental study. Risk Anal. Int. J. 29, 1141-1155. doi: 10.1111/j.1539-6924.2009.01252.x

Thomas, T. N., Sobelson, R. K., Wigington, C. J., Davis, A. L., Harp, V. H., LeanderGriffith, M., et al. (2018). Applying instructional design strategies and behavior theory to household disaster preparedness training. J. Public Health Manage. Prac. 24, e16-e25. doi: 10.1097/PHH.0000000000000511

Toronto Water (2020). 2020 Basement Flooding Protection Program Update. IE17.5 Report for Action (Toronto, ON).
Town of Tecumseh (2016). Town of Tecumseh Flooding Event. News Release Alexandria, VA: Town of Tecumseh.

Utilities Kingston (2021). Basement Flooding: How Do Sewers Work in the City of Kingston? Available online at: https://utilitieskingston.com/Wastewater/ BasementFlooding/Flooded/Report/Sewers (accessed March 10, 2021).

Water Environment Federation (2006). Methods for Cost-Effective Rehabilitation of Private Lateral Sewers. Alexandria: Water Environment Research Foundation. doi: 10.2175/193864706783796321

Webber, J. L., Fletcher, T. D., Cunningham, L., Fu, G., Butler, D., and Burns, M. J. (2020). Is green infrastructure a viable strategy for managing urban surface water flooding? Urban Water J. 17, 598-608. doi: 10.1080/1573062X.2019.1700286

White, E., Knighton, J., Martens, G., Plourde, M., and Rajan, R. (2013). Geoprocessing tools for surface and basement flooding analysis in SWMM. J. Water Manage. Model. R246-03. doi: 10.14796/JWMM.R246-03

Wilkinson, B. (1985). "Rising groundwater levels in London and possible effects on engineering structures," in Proceedings of the 18th Congress of the IAH (Cambridge), 145-157.

Worsely, B. (2005). City of Peterborough Flood Reduction Master Plan. Peterborough, ON: City of Peterborough; UMA/AECOM.

Yang, L., Smith, J. A., Baeck, M. L., and Zhang, Y. (2016). Flash flooding in small urban watersheds: storm event hydrologic response. Water Resour. Res. 52, 4571-4589. doi: 10.1002/2015WR0 18326

York Region (n.d.). Sewage Backup Factsheet. Available online at: https:// www.york.ca/wps/wcm/connect/yorkpublic/4eafdce0-c877-4812-b466b8c5e920c519/Sewage_back-up_factsheet.pdf?MOD=AJPERES (accessed March 10, 2021).

Zhu, Z., and Chen, X. (2017). Evaluating the effects of low impact development practices on urban flooding under different rainfall intensities. Water 9:548. doi: 10.3390/w9070548

Conflict of Interest: The authors declare that the research was conducted in the absence of any commercial or financial relationships that could be construed as a potential conflict of interest.

Publisher's Note: All claims expressed in this article are solely those of the authors and do not necessarily represent those of their affiliated organizations, or those of the publisher, the editors and the reviewers. Any product that may be evaluated in this article, or claim that may be made by its manufacturer, is not guaranteed or endorsed by the publisher.

Copyright (C) 2021 Sandink and Binns. This is an open-access article distributed under the terms of the Creative Commons Attribution License (CC BY). The use, distribution or reproduction in other forums is permitted, provided the original author(s) and the copyright owner(s) are credited and that the original publication in this journal is cited, in accordance with accepted academic practice. No use, distribution or reproduction is permitted which does not comply with these terms. 